\title{
Association of vitamin D status with COVID-19 and its severity
}

\author{
Vitamin D and COVID-19: a narrative review
}

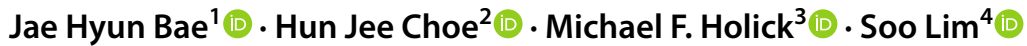

Accepted: 14 December 2021 / Published online: 4 January 2022

๑ The Author(s), under exclusive licence to Springer Science+Business Media, LLC, part of Springer Nature 2022

\begin{abstract}
Vitamin D is associated with biological activities of the innate and adaptive immune systems, as well as inflammation. In observational studies, an inverse relationship has been found between serum 25-hydroxyvitamin $\mathrm{D}(25(\mathrm{OH}) \mathrm{D})$ concentrations and the risk or severity of coronavirus disease 2019 (COVID-19). Several mechanisms have been proposed for the role of vitamin D in COVID-19, including modulation of immune and inflammatory responses, regulation of the renin-angiotensin-aldosterone system, and involvement in glucose metabolism and cardiovascular system. Low 25(OH) D concentrations might predispose patients with COVID-19 to severe outcomes not only via the associated hyperinflammatory syndrome but also by worsening preexisting impaired glucose metabolism and cardiovascular diseases. Some randomized controlled trials have shown that vitamin D supplementation is beneficial for reducing severe acute respiratory syndrome coronavirus 2 RNA positivity but not for reducing intensive care unit admission or all-cause mortality in patients with moderate-to-severe COVID-19. Current evidence suggests that taking a vitamin D supplement to maintain a serum concentration of $25(\mathrm{OH}) \mathrm{D}$ of at least $30 \mathrm{ng} / \mathrm{mL}$ (preferred range $40-60 \mathrm{ng} / \mathrm{mL}$ ), can help reduce the risk of COVID-19 and its severe outcomes, including mortality. Although further well designed studies are warranted, it is prudent to recommend vitamin D supplements to people with vitamin D deficiency/insufficiency during the COVID-19 pandemic according to international guidelines.
\end{abstract}

Keywords Vitamin D · COVID-19 · Immunomodulation · Inflammation · Renin-angiotensin-aldosterone system

Jae Hyun Bae and Hun Jee Choe contributed to this article equally.

Soo Lim

limsoo@snu.ac.kr

Michael F. Holick

mfholick@bu.edu

1 Department of Internal Medicine, Korea University Anam Hospital, Korea University College of Medicine, Seoul, South Korea

2 Department of Internal Medicine, Seoul National University Hospital, Seoul, South Korea

3 Section of Endocrinology, Diabetes, Nutrition and Weight Management, Department of Medicine, Boston University Medical Campus, 715 Albany St \#437, Boston, MA 02118, USA

4 Department of Internal Medicine, Seoul National University College of Medicine, Seoul National University Bundang Hospital, 82, Gumi-ro, 173 Beon-gil, Bundang-gu, Seongnam 13620, South Korea

\section{Acronyms and abbreviations}

$\begin{array}{ll}1,25(\mathrm{OH})_{2} \mathrm{D} & \text { 1,25-Dihydroxyvitamin D } \\ 25(\mathrm{OH}) \mathrm{D} & \text { 25-Hydroxyvitamin D } \\ \text { ACE2 } & \text { Angiotensin-converting enzyme 2 } \\ \text { AMP } & \text { Antimicrobial peptide } \\ \text { ARDS } & \text { Acute respiratory distress syndrome } \\ \mathrm{CD} & \text { Cluster of differentiation } \\ \text { CI } & \text { Confidence interval } \\ \text { COVID-19 } & \text { Coronavirus disease 2019 } \\ \text { CVD } & \text { Cardiovascular disease } \\ \text { DM } & \text { Diabetes mellitus } \\ \text { ICU } & \text { Intensive care unit } \\ \text { IFN } & \text { Interferon } \\ \text { IL } & \text { Interleukin } \\ \text { LPS } & \text { Lipopolysaccharide } \\ \text { MAPK } & \text { Mitogen-activated protein kinase } \\ \text { NF- } \mathrm{B} & \text { Nuclear factor kappa-light-chain-enhancer } \\ & \text { of activated B cells } \\ \text { OR } & \text { Odds ratio } \\ \text { RAAS } & \text { Renin-angiotensin-aldosterone system }\end{array}$




\begin{tabular}{|c|c|}
\hline RANKL & $\begin{array}{l}\text { Receptor activator of nuclear factor- } \mathrm{\kappa B} \\
\text { ligand }\end{array}$ \\
\hline RCT & Randomized controlled trial \\
\hline RNA & Ribonucleic acid \\
\hline ROS & Reactive oxygen species \\
\hline SARS-CoV & $\begin{array}{l}\text { Severe acute respiratory syndrome } \\
\text { coronavirus }\end{array}$ \\
\hline SARS-CoV-2 & $\begin{array}{l}\text { Severe acute respiratory syndrome } \\
\text { coronavirus } 2\end{array}$ \\
\hline SIRS & $\begin{array}{l}\text { Systemic inflammatory response } \\
\text { syndrome }\end{array}$ \\
\hline TGF- $\beta$ & Transforming growth factor- $\beta$ \\
\hline Th1 & Type 1 helper $\mathrm{T}$ \\
\hline TLR & Toll-like receptor \\
\hline TNF & Tumor necrosis factor \\
\hline VDR & Vitamin D receptor \\
\hline VITAL & VITamin D and OmegA-3 Trial \\
\hline
\end{tabular}

\section{Introduction}

The prevalence of vitamin $\mathrm{D}$ deficiency, estimated at a serum concentration $<20 \mathrm{ng} / \mathrm{mL}$ of 25 -hydroxyvitamin D $(25(\mathrm{OH}) \mathrm{D})$, as defined by the Endocrine Society's Practice Guidelines on Vitamin D [1], varies according to age, region, and ethnicity [2]. However, vitamin D deficiency is relatively common [3], especially among the elderly [4, 5]. A study of 191,779 severe acute respiratory syndrome coronavirus 2 (SARS-CoV-2)-positive patients found a strong inverse relationship between SARS-CoV-2 positivity rates and serum $25(\mathrm{OH}) \mathrm{D}$ concentrations determined in the preceding 12 months (Supplementary Fig. S1) [6]. Compared with patients who had serum $25(\mathrm{OH}) \mathrm{D}$ concentrations $<20 \mathrm{ng} / \mathrm{mL}$, those with concentrations of 30-34 ng/ $\mathrm{mL}$ were at a lower risk of SARS-CoV-2 infection (12.5\% vs. 8.1\%) [6]. This relationship persisted across sexes, races/ethnicities, latitudes, and age ranges and continued its downward trend in infectivity until the serum concentration reached $55 \mathrm{ng} / \mathrm{mL}$ (5.9\%; 95\% confidence interval (CI) 5.5\%-6.4\%) [6]. Another study of 489 individuals who had $25(\mathrm{OH}) \mathrm{D}$ concentrations measured in the year before COVID-19 testing found that the relative risk of testing positive for COVID-19 was 1.77 times greater for those who were deficient in vitamin $\mathrm{D}$ than for those in whom it was sufficient $(P=0.02)$ [7].

There is a considerable overlap between risk factors for vitamin D deficiency and COVID-19, including older age, obesity, dark skin tone, being Black, Asian, and minority ethnic groups, or living in northerly latitudes [8-10]. These factors are significantly associated with increased morbidity and mortality in patients with COVID-19 [10-14]. A systematic review found that low serum concentrations of $25(\mathrm{OH})$ D were associated with increased mortality and severity of
COVID-19 [15]. Thus, vitamin D deficiency appears to be associated with severe COVID-19 outcomes (Table 1). From a different context, several studies have investigated whether vitamin D supplementation could reduce COVID-19 susceptibility or severity. In a pilot randomized controlled trial (RCT), including 76 patients hospitalized for COVID-19, oral administration of high-dose calcifediol $(25(\mathrm{OH}) \mathrm{D} 3$; $0.532 \mathrm{mg}$ on the day of admission and $0.266 \mathrm{mg}$ on days 3 and 7 and weekly thereafter) reduced intensive care unit (ICU) admission [16]. In another study of SARS-CoV-2 RNA-positive patients in India, 10 (63\%) participants in the intervention group and $5(21 \%)$ in the control group became SARS-CoV-2 RNA-negative after 60,000 IU of vitamin D3 (cholecalciferol) supplementation for 14 days $(P<0.018)$ [17]. These data suggest that vitamin D sufficiency might have protective effects against COVID-19.

SARS-CoV-2 infection causes cellular and tissue damage and triggers innate and adaptive immune responses [18]. Vitamin D is associated with immunological activities by regulating important components of the innate and adaptive immune systems and inflammation [19]. Thus, several mechanisms have been proposed for the role of vitamin D in COVID-19, including modulation of immune and inflammatory responses [20] and regulation of the renin-angiotensin-aldosterone system (RAAS) [21, 22]. Given these pleiotropic effects, vitamin D could have beneficial effects on the prevention and treatment of COVID-19 $[23,24]$. Here, we review the current evidence suggesting a role for vitamin $\mathrm{D}$ and its therapeutic potential in the management of patients with COVID-19.

\section{Pathophysiological relationships between vitamin D and COVID-19}

Vitamin D is synthesized in the skin after exposure to ultraviolet $B$ radiation or is obtained from food and supplements. It undergoes 25 - and $1 \alpha$-hydroxylation sequentially in the liver and kidney, respectively, thereby converting it to 1,25-dihydroxyvitamin $\mathrm{D}\left(1,25(\mathrm{OH})_{2} \mathrm{D}\right)$, its biologically active form [25]. Vitamin D and its metabolites can affect SARS-CoV-2 infection and the severity of COVID-19 in several ways (Table 2). These include their effects on the immune system, inflammation, fibrosis, RAAS, acute lung injury, glucose metabolism, and cardiovascular risk.

\subsection{Role of vitamin $D$ in the immune system}

Vitamin D metabolic enzymes and the vitamin D receptor (VDR) are present in most cells involved in the innate and adaptive immune system [26]. Importantly, these immune cells produce $1,25(\mathrm{OH})_{2} \mathrm{D}$ locally, which has an immunoregulatory action against invading pathogens [27]. In addition, 


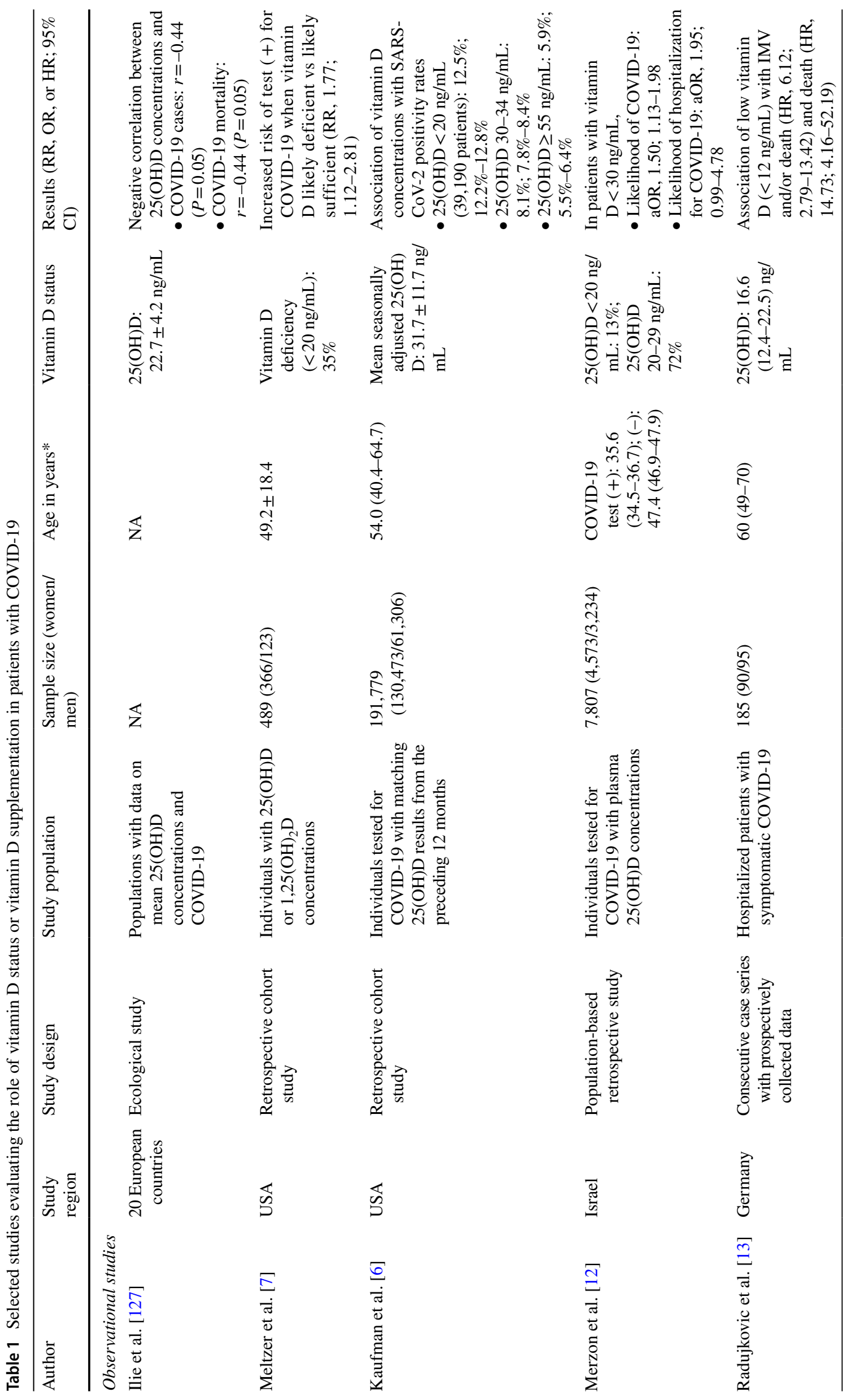




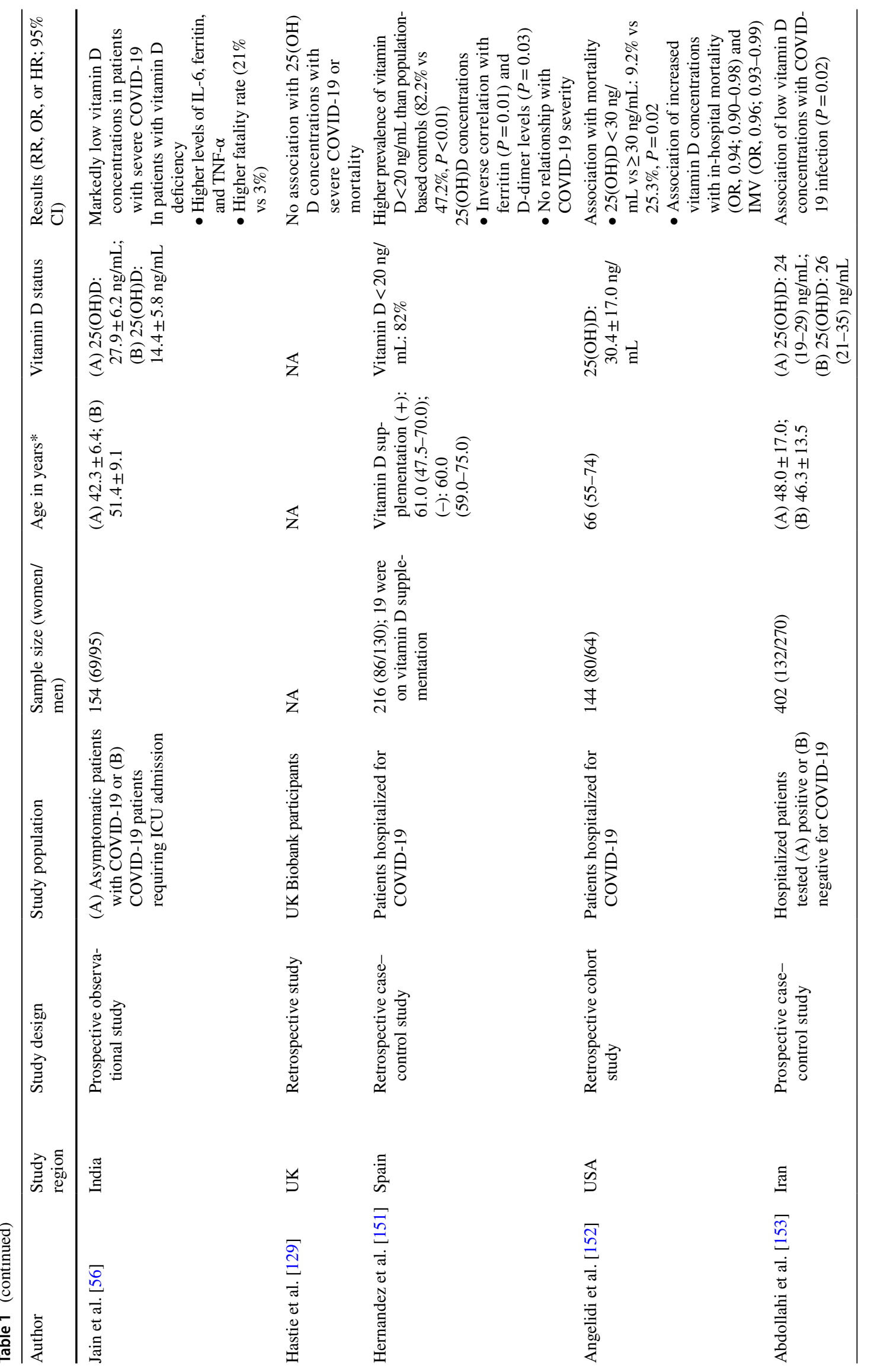




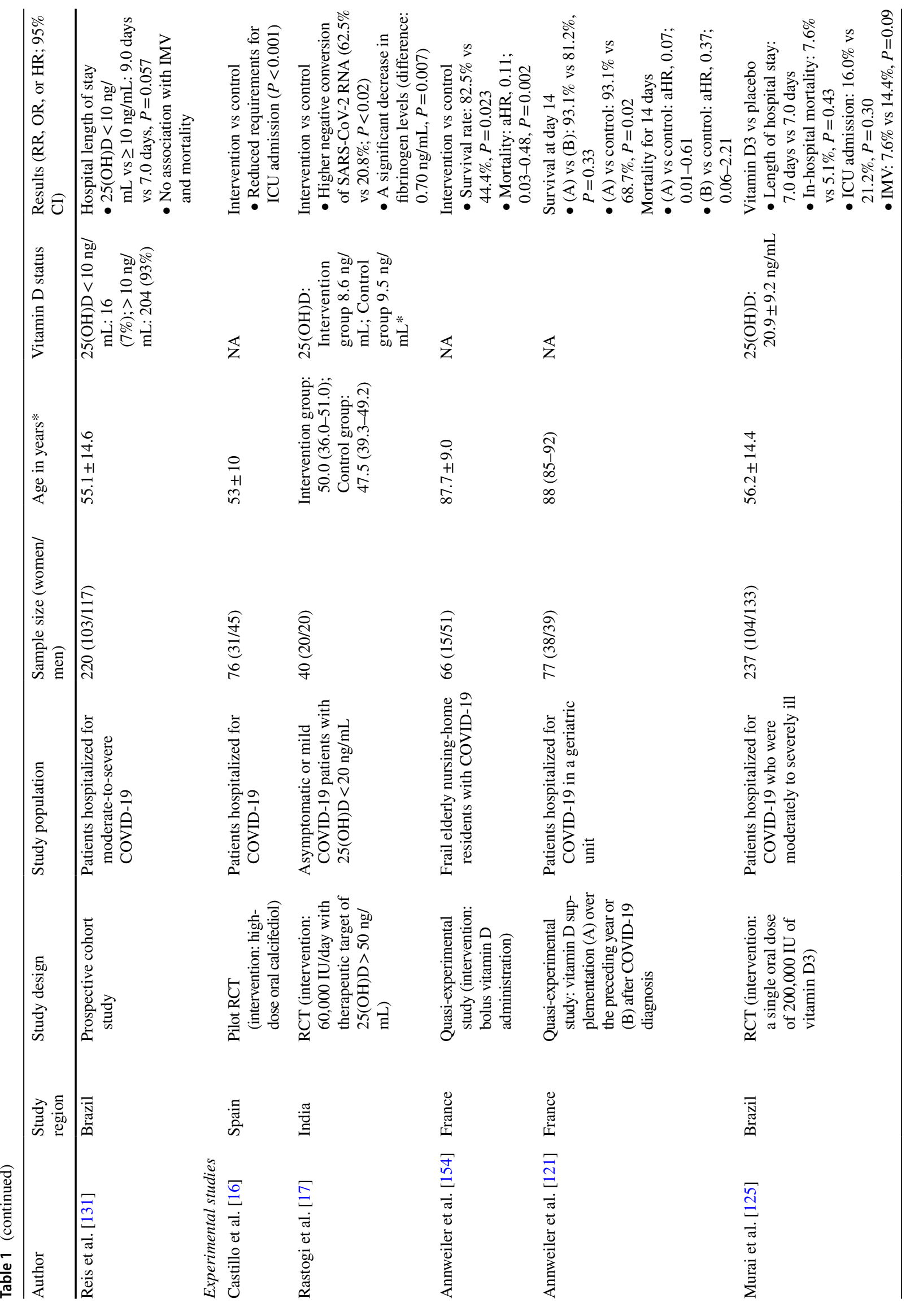




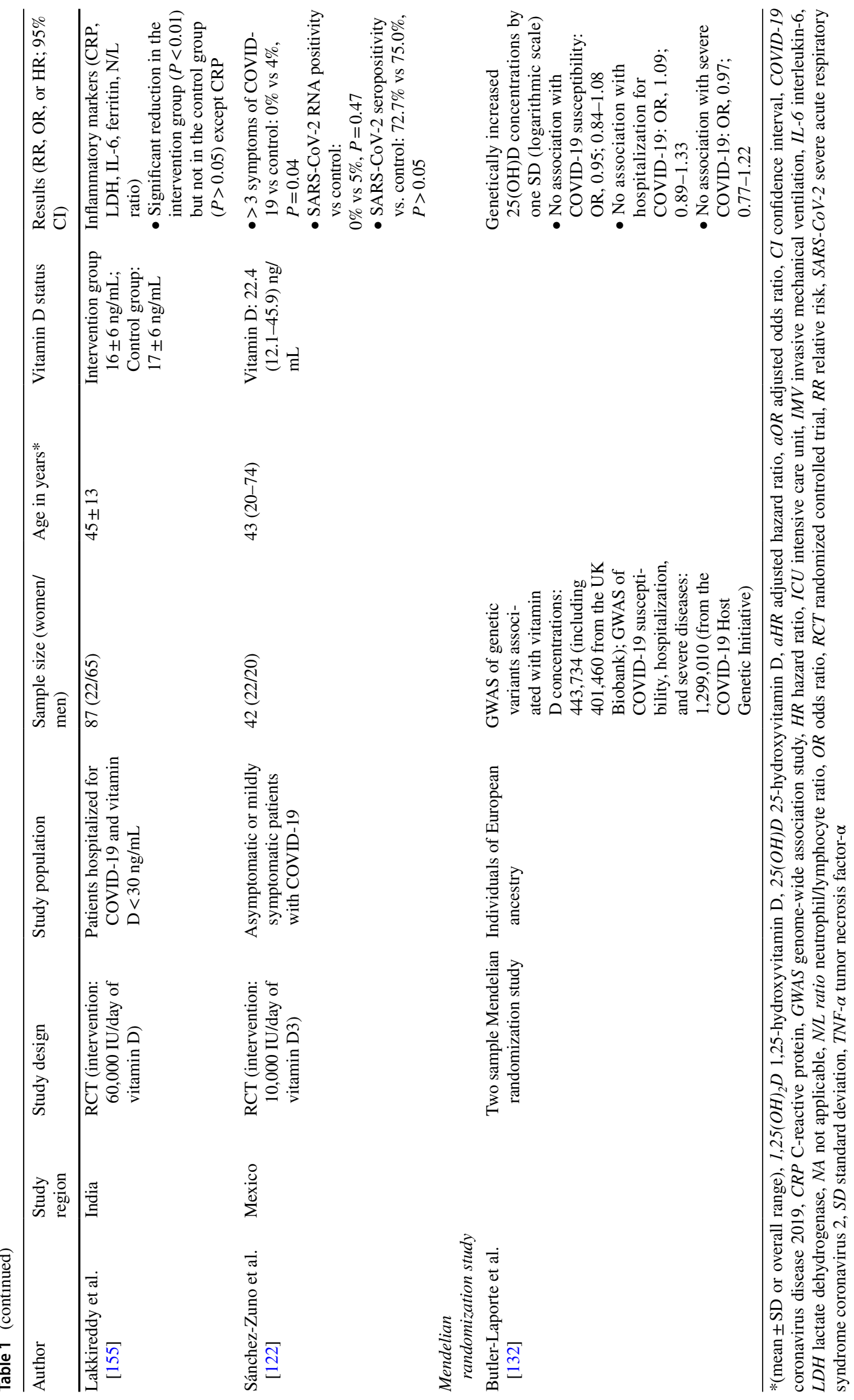


Table 2 Potential effects of vitamin D on the risks and prognosis for patients with COVID-19

\begin{tabular}{|c|c|c|}
\hline Categories & Possible effects & Mechanisms \\
\hline Immune system & $\begin{array}{l}\text { Modulating the risk of infection, attenuating excessive } \\
\text { immune response }\end{array}$ & $\begin{array}{l}\text { Innate immunity } \\
\text { - Monocytes and macrophages: } \uparrow \text { proliferation [28], } \\
\uparrow \text { antimicrobial peptides production (cathelicidins, } \\
\text { defensins) [156], } \uparrow \text { autophagy [29] } \\
\text { - Dendritic cells: } \downarrow \text { maturation [45], } \downarrow \text { MHC class II [45], } \\
\downarrow \text { co-stimulatory molecules (CD40, CD80, CD86) [45], } \\
\uparrow \text { inhibitory molecules (PD-L1)[157] } \\
\text { Adaptive immunity } \\
\text { - T cells: } \downarrow \text { proliferation [158], } \downarrow \text { Th1 (IFN- } \gamma \text { ) [159] and } \\
\text { Th17 (IL-17) [160] responses, } \uparrow \text { Th2 (IL-4, IL-5) [161] } \\
\text { and Treg (IL-10) [157] responses } \\
\text { - B cells: } \downarrow \text { proliferation }[162], \downarrow \text { differentiation into plasma } \\
\text { cell [162], } \downarrow \text { Ig production (IgG, IgM) [163] }\end{array}$ \\
\hline Inflammation & Anti-inflammation & $\begin{array}{l}\downarrow \text { TLR signaling [164], } \downarrow \text { NF- } \kappa B ~[165], \downarrow \text { prostaglandins } \\
{[166], \uparrow \text { MAPK phosphatases }[59], \downarrow \text { proinflammatory }} \\
\text { cytokines (IL-6, TNF- } \alpha \text { ) [167], } \uparrow \text { inhibitory cytokines (IL- } \\
\text { 10, TGF- } \beta \text { ) [157] }\end{array}$ \\
\hline Fibrosis & Antifibrotic effect & $\begin{array}{l}\downarrow \text { Epithelial-mesenchymal transition [168], } \downarrow \text { fibroblast } \\
\quad \text { differentiation [169], } \uparrow \text { profibrotic factors (TGF- } \beta \text {, } \\
\text { SERPINE1) [170], } \uparrow \text { antifibrotic factors (BMP-7, } \\
\text { MMP-8, follistatin) [170], } \downarrow \text { collagen expression [170], } \\
\downarrow \text { MCP-1 [171] }\end{array}$ \\
\hline RAAS & $\begin{array}{l}\text { Alleviating lung injury, improving outcome of } \\
\text { preexisting CVD or reducing incident CVD }\end{array}$ & $\begin{array}{l}\text { Classic pathway (ACE2/angiotensin-(1-7)/Mas receptor): } \\
\uparrow \text { ACE2[21] } \\
\text { Counter-regulatory pathway (angiotensin II/AT1R): } \downarrow \text { renin } \\
\text { expression [21], } \downarrow \text { ACE [21], } \downarrow \text { angiotensin II expression } \\
{[21]}\end{array}$ \\
\hline ARDS & $\begin{array}{l}\text { Reducing the risk of ARDS, } \\
\text { promoting the recovery from lung injury }\end{array}$ & $\begin{array}{l}\text { Epithelial barrier integrity: } \downarrow \text { extravascular lung water index } \\
{[172], \downarrow \text { pulmonary vascular permeability index [172] }} \\
\text { Epithelial injury: } \downarrow \text { RAGE (bronchoalveolar lavage fluid) } \\
{[172], \downarrow \text { protein permeability index [172] }} \\
\text { Inflammation: } \downarrow \text { TNF- } \alpha[172], \downarrow \text { VEGF }[172], \downarrow \text { CXCL1 } \\
{[172]} \\
\text { Apoptosis: } \downarrow \text { soluble Fas ligand-mediated cell death [172] } \\
\uparrow \text { Scratch wound healing [172] }\end{array}$ \\
\hline Glucose metabolism & $\begin{array}{l}\text { Improving outcomes of COVID-19 associated with } \\
\text { hyperglycemia }\end{array}$ & $\begin{array}{l}\text { T1DM: } \downarrow \text { insulitis [173], } \uparrow \beta \text {-cell survival [173], } \downarrow \text { disease } \\
\text { onset [173], } \downarrow \text { disease progression [174] } \\
\text { T2DM: } \uparrow \beta \text {-cell function [175], } \downarrow \text { islet inflammation [175], } \\
\downarrow \text { islet RAAS components [176], } \downarrow \text { hyperglycemia [175], } \\
\downarrow \text { disease progression }[175]\end{array}$ \\
\hline CVD & Improving the prognosis of COVID-19 & $\begin{array}{l}\text { RAAS inhibition [65], } \downarrow \text { cardiac hypertrophy [177], } \\
\uparrow \text { myocardial contractility [177], } \uparrow \text { endothelial function } \\
\text { [177], } \downarrow \text { mortality [178] }\end{array}$ \\
\hline
\end{tabular}

$A C E$ angiotensin-converting enzyme, $A C E 2$ angiotensin-converting enzyme 2, ATIR angiotensin II type 1 receptor, $A R D S$ acute respiratory distress syndrome, $B M P-7$ bone morphogenic protein-7, $C D$ cluster of differentiation, COVID-19 coronavirus disease 2019, $C V D$ cardiovascular disease, $C X C L 1$ chemokine ligand $1, I F N$ interferon, $I g$ immunoglobulin, $I L$ interleukin, MAPK mitogen-activated protein kinase, $M C P-1$ monocyte chemoattractant protein-1, $M H C$ major histocompatibility complex, $M M P-8$ matrix metalloproteinase- $8, N F-\kappa B$ nuclear factor kappalight-chain-enhancer of activated $\mathrm{B}$ cells, $P D-L 1$ programmed death ligand-1, $R A A S$ renin-angiotensin-aldosterone system, $R A G E$ receptor for advanced glycation end products, T1DM and T2DM type 1 and type 2 diabetes mellitus, Th T helper cell, TLR toll-like receptor, Treg regulatory T cell, $T G F-\beta$ transforming growth factor- $\beta, T N F-\alpha$ tumor necrosis factor- $\alpha, V E G F$ vascular endothelial growth factor

$25(\mathrm{OH}) \mathrm{D}$ is metabolized to $1,25(\mathrm{OH})_{2} \mathrm{D}$ in innate and adaptive immune cells [28]. This locally produced $1,25(\mathrm{OH})_{2} \mathrm{D}$ acts on the immune cells in autocrine and paracrine manners, exerting immunomodulatory effects [28, 29].

The VDR is a regulator of innate and adaptive immunity [29]. A meta-analysis of case-controlled studies showed that VDR gene polymorphisms were associated with susceptibility to enveloped virus infection, such as Respiratory Syncytial Virus [30]. VDR can also act as a checkpoint regulating inflammatory responses after tissue injury [31]. VDR agonists silence transforming growth factor $\beta$ (TGF- $\beta$ ) signaling [32], potentially 
inhibiting proinflammatory and profibrotic changes [31]. Certain toll-like receptor (TLR) signals induce the expression of VDR [28]. However, a recent study found that the expression of VDR was lower in patients with COVID-19 than in controls [33], which requires further investigation.

\subsubsection{Innate immunity}

Innate immune cells can prevent infections by producing antimicrobial peptides (AMPs) such as cathelicidins and defensins [34]. AMPs are an important component of innate immunity and are induced upon recognition of pathogenassociated molecular patterns [35]. A consensus sequence for the vitamin D response element was identified in the promoter regions of human genes for cathelicidin antimicrobial peptide (CAMP) and $\beta$-defensin-2 (DEFB4), and its expression was strongly upregulated by $1,25(\mathrm{OH})_{2} \mathrm{D}[36$, 37]. $1,25(\mathrm{OH})_{2} \mathrm{D}$ induced autophagy in monocytes and macrophages via cathelicidin in vitro, with antimycobacterial effects [38]. A preliminary study found that oral administration of human cathelicidin, LL-37, ameliorated systemic symptoms in 11 patients with mild COVID-19 [39]. These findings suggest that improvement in vitamin $\mathrm{D}$ status, by providing more substrate (i.e., $25(\mathrm{OH}) \mathrm{D}$ ) to immune cells capable of converting it to $1,25(\mathrm{OH})_{2} \mathrm{D}$, might be a crucial constituent of the early host defense against SARS-CoV-2 infection through the production of AMPs.

\subsubsection{Adaptive immunity}

The adaptive immune system in which vitamin D is involved can act as a 'double-edged sword' in patients with COVID19 [40]. An appropriate immune response to SARS-CoV-2 infection is necessary for viral clearance and mitigates adverse outcomes in patients with COVID-19. However, overproduction of proinflammatory cytokines can contribute to an uncontrolled excessive immune response, known as a cytokine storm [41]. This dysfunctional immune response has detrimental consequences, such as systemic inflammatory response syndrome (SIRS) and multiorgan failure [18].

Vitamin D and its metabolites are associated with both $\mathrm{T}$ and $\mathrm{B}$ cell immunity. In general, $\mathrm{T}$ cell responses play a pivotal role in combatting viral infections. Dysregulated T cell responses can lead to a pathological response to such infections [42]. Emerging evidence suggests that patients with severe COVID-19 are characterized by the functional exhaustion of T cells [43] and that improvements in vitamin D status can alleviate this process through immunomodulation [29]. 1,25(OH $)_{2} \mathrm{D}$ impairs the maturation of dendritic cells in a paracrine manner and renders them tolerogenic [44]. Because tolerogenic dendritic cells feature phenotypes resembling immature dendritic cells, $1,25(\mathrm{OH})_{2} \mathrm{D}$ reduces the differentiation of naïve $\mathrm{T}$ cells into cytotoxic effector $\mathrm{T}$ cells $[29,45]$. In addition, $1,25(\mathrm{OH})_{2} \mathrm{D}$ directly suppresses $\mathrm{T}$ cell activation by reducing the type 1 helper $\mathrm{T}$ cell $(\mathrm{Th} 1)$ and type 17 helper $T$ cell responses [46]. This is mediated by the binding of $1,25(\mathrm{OH})_{2} \mathrm{D}$ to the VDR and subsequent translocation to the nucleus of $\mathrm{T}$ cells, which upregulates the expression of the gene for cytotoxic T-lymphocyte antigen 4 (CTLA4), cluster of differentiation 38 (CD38), and interleukin-10 (IL-10) [47]. As $\mathrm{CD}^{+}{ }^{+} \mathrm{T}$ cells are Th1skewed in the bronchoalveolar lavage fluid of SARS-CoV2-infected patients, $1,25(\mathrm{OH})_{2} \mathrm{D}$ might alleviate uncontrolled excessive immune responses by promoting a transition from proinflammatory interferon- $\gamma$ (IFN- $\gamma$ )-positive Th1 cells to inhibitory IL-10 ${ }^{+}$Th1 cells [47]. Although T cell dynamics in COVID-19 need further investigation, the evidence suggests that improving vitamin $\mathrm{D}$ status can be beneficial in reducing dysregulated $\mathrm{T}$ cell responses.

Vitamin D is also associated with B cell immunity. VDR is expressed in $\mathrm{B}$ cells and $1,25(\mathrm{OH})_{2} \mathrm{D}$ directly reduces the proliferation of these cells and promotes the secretion of IL-10, which in turn suppresses the activation of Th1 and subsequently reduces inflammation [29]. These properties of locally produced $1,25(\mathrm{OH})_{2} \mathrm{D}$ might alter $\mathrm{B}$ cell responses in patients with COVID-19. Of note, B cells are also involved in immunological memory and viral clearance. More studies are needed to elucidate the additional role of improved vitamin D status on B cell function and immunity. On the other hand, alterations in adaptive immunity and vitamin D status can affect the prognosis of COVID-19 by affecting bone metabolism. Under inflammatory conditions, the release of cytokines, such as tumor necrosis factor (TNF), IL-6, and IL-1, can upregulate osteoclastogenesis and inhibit osteoblast activities [48]. Among these cytokines, TNF is a key factor in bone loss and might synergize with the receptor activator of nuclear factor kappa-B ligand (RANKL) to induce osteoclastic bone resorption [49]. Activated T and B cells serve as major sources of RANKL and TNF in inflammatory states [49]. In murine macrophage cells, $3 \mathrm{a} / \mathrm{X} 1$, an accessory protein of SARS-CoV, promoted osteoclastogenesis by upregulating TNF- $\alpha$ [50]. From a different point of view, SARS-CoV-2 infection might be harmful to bone metabolism. The use of corticosteroids for the treatment of patients with COVID-19 is likely to have detrimental effects on bone health [51]. Increased numbers of vertebral fractures caused by vitamin $\mathrm{D}$ deficiency in such patients exacerbate the clinical outcomes [52]. In this regard, the role of vitamin $\mathrm{D}$ should be also evaluated from osteo-metabolic perspectives in patients with COVID-19.

\subsection{Association of vitamin D with inflammation}

SARS-CoV-2 infection elicits local and systemic inflammatory responses in humans [53]. Hyperinflammation, 
accompanied by an excessive immune response, induces pyroptosis, tissue damage, and SIRS in patients with COVID-19 [18]. When SARS-CoV-2 infects the lungs, it causes alveolar epithelial cell death, endothelial disruption, increased lung permeability, and alveolar edema, and can lead to acute respiratory distress syndrome (ARDS) and multiorgan failure [54]. After SARS-CoV-2 infection, recognition of the virus by pattern-recognition receptors, such as TLRs, induces the production of proinflammatory cytokines such as IL-6, IL-12, IFN- $\gamma$, and TNF- $\alpha[53,55]$. Of these, elevations of IL- 6 and TNF- $\alpha$ levels have been associated with hyperinflammatory status, procoagulant profiles, and worse disease severity in patients with COVID-19 [42].

An association of vitamin D deficiency with inflammation in patients with COVID-19 has been reported. In a prospective study of 154 COVID-19 patients, serum 25(OH)D concentrations were significantly lower in patients requiring ICU admission than in asymptomatic patients [56]. Inflammatory responses, along with IL- 6 , TNF- $\alpha$, and ferritin levels, were increased in COVID-19 patients with serum $25(\mathrm{OH}) \mathrm{D}<20 \mathrm{ng} / \mathrm{mL}$ [56]. Large-scale data analysis shows a possible link between vitamin D deficiency and high fatality rates with COVID-19 across countries, thereby suggesting the role of vitamin $\mathrm{D}$ in preventing hyperinflammation [57].

Vitamin D has been reported to have anti-inflammatory effects. In a systematic review of human-derived immune cell studies, vitamin $\mathrm{D} 3$, including $1,25(\mathrm{OH})_{2} \mathrm{D} 3$ used in most of the studies as well as $25(\mathrm{OH}) \mathrm{D} 3$, reduced the levels of inflammatory cytokines and reactive oxygen species (ROS) [58]. In vitro studies showed that when the monocyte and macrophages were preincubated with $\geq 30 \mathrm{ng} / \mathrm{mL}$ of $25(\mathrm{OH}) \mathrm{D} 3$, a significant inhibition of lipopolysaccharide (LPS)-induced IL-6 mRNA expression was observed $(P<0.01)$, whereas there was no such inhibition when the cells were cultured with $15 \mathrm{ng} / \mathrm{mL}$ of $25(\mathrm{OH}) \mathrm{D} 3$. The active form of vitamin $\mathrm{D}, 1,25(\mathrm{OH})_{2} \mathrm{D} 3$, also significantly inhibited LPS-induced IL-6 mRNA expression [59]. The degree of suppression of IL- $6 \mathrm{mRNA}$ expression by $30 \mathrm{ng} / \mathrm{mL}$ of $25(\mathrm{OH}) \mathrm{D} 3$ was similar to that achieved with $0.04 \mathrm{ng} / \mathrm{mL}$ of $1,25(\mathrm{OH})_{2} \mathrm{D} 3$ [59]. Similar effects of $1,25(\mathrm{OH})_{2} \mathrm{D} 3$ were also observed in LPS-induced TNF- $\alpha$ mRNA expression [59]. Therefore, these data support observations that when a patient with COVID-19 is vitamin D sufficient, the morbidity and mortality rates are lower, probably from the downregulated production of proinflammatory cytokines, while increasing the production of inhibitory cytokines in monocytes and macrophages [59]. Genome- and transcriptomewide studies showed that $1,25(\mathrm{OH})_{2} \mathrm{D} 3$ exerted antiinflammatory effects by modulation of prostaglandin, nuclear factor kappa-light-chain-enhancer of activated B cells (NF$\kappa \mathrm{B}$ ), and mitogen-activated protein kinase (MAPK) phosphatase 5 signaling pathways [60]. $1,25(\mathrm{OH})_{2} \mathrm{D} 3 \mathrm{might}$ reduce inflammation by promoting nitric oxide production, inhibiting ROS generation, and preventing endothelial cell dysfunction [61].

Dexamethasone is an anti-inflammatory agent that has demonstrated improved outcomes regarding mortality in patients with COVID-19 receiving respiratory support [62]. A structure-activity relationship of dexamethasone with SARS-CoV-2 spike protein has been unraveled recently; the binding of dexamethasone to the fatty acid binding site in the SARS-CoV-2 stabilizes the locked spike conformation, interfering with the angiotensin-converting enzyme 2 (ACE2) receptor binding [63]. As vitamin $\mathrm{D}$ and dexamethasone are structurally similar and share the same fatty acid binding site [63], vitamin D could be a potential adjuvant treatment for reducing inflammation, although careful assessment of who might benefit from this therapy is warranted.

\subsection{Vitamin D and the RAAS}

Dysregulation of the RAAS predisposes patients to severe COVID-19 after SARS-CoV2 infection [64]. Low circulating concentrations of $25(\mathrm{OH}) \mathrm{D}$ cause inappropriate activation of this system $[65,66]$. This is linked to deterioration in the cardiovascular system, which is the main mechanism for mortality in patients with COVID-19 [67].

SARS-CoV-2 enters the human body by binding to ACE2, which serves as the host cell receptor. Upregulation of the angiotensin II/angiotensin type 1 receptor axis and downregulation of the angiotensin-(1-7)/Mas receptor or the ACE2 receptor axis can induce inflammation, oxidative stress, apoptosis, high blood pressure, vascular dysfunction, and cardiovascular remodeling in these patients [64, 68]. In a prospective cohort study conducted in Germany, low serum concentrations of both $25(\mathrm{OH}) \mathrm{D}$ and $1,25(\mathrm{OH})_{2} \mathrm{D}$ were found to be independently associated with increased RAAS activity in individuals who were referred for coronary angiography [69]. In mice, chronic vitamin D deficiency induced lung fibrosis through activation of the RAAS [70]. By contrast, administration of calcitriol $\left(1,25(\mathrm{OH})_{2} \mathrm{D} 3\right)$, the active metabolite of vitamin D, alleviated LPS-induced acute lung injury by regulating the RAAS in rats [21]. This also increased the expression of ACE2 [21]. Initially, there were concerns on whether increased expression of ACE2 might increase the risk of SARS-CoV-2 infection. However, studies now claim that expression of ACE2 upregulates the angiotensin-(1-7)/Mas receptor axis, which alleviates acute lung injury and ARDS during COVID-19. These findings suggest that improvement in the circulating concentrations of $25(\mathrm{OH}) \mathrm{D}$ and locally produced $1,25(\mathrm{OH})_{2} \mathrm{D}$ might have different effects depending on the stage of COVID-19, although the overall effects are considered beneficial [71]. Further studies are required to clarify the role of vitamin D in the RAAS among patients with COVID-19. 


\subsection{Relationship between vitamin $D$ and glucose homoeostasis}

Increased severity of COVID-19 in patients with diabetes mellitus (DM) has been reported [72]. Interacting with other risk factors, hyperglycemia might modulate immune and inflammatory responses, thus predisposing patients to severe COVID-19 and possible lethal outcomes [68]. Vitamin D insufficiency, defined as a $25(\mathrm{OH}) \mathrm{D}$ concentration of 20-29 ng/mL, is associated with impaired glucose homoeostasis, an established risk factor for COVID-19 [73]. Several studies have reported that optimal vitamin $\mathrm{D}$ homoeostasis is essential for pancreatic $\beta$-cell function and insulin sensitivity [74-76]. 1,25(OH) $)_{2} \mathrm{D} 3$ and calcium regulate the transcription of calcium transporter genes [77]. VDR gene suppression results in a decrease of intracellular $\mathrm{Ca}^{2+}$ concentrations [78]. Thus, vitamin D deficiency/insufficiency is likely to contribute to impaired glycemic control by disturbing calcium balance [79]. In some mouse models, vitamin D deficiency inhibits insulin secretion, resulting in hyperglycemia [80, 81]. Clearly, ancillary analysis from The VITamin D and OmegA-3 TriaL (VITAL) [82] and future clinical trials of higher-dose vitamin D supplementation are warranted to clarify any beneficial effects of vitamin D on the primary prevention of type $2 \mathrm{DM}$.

Vitamin D plays a role in controlling both gene transcription and cell signaling pathways and alleviates the onset of insulin resistance, especially in adipose tissue [83]. Of note, pulmonary lipofibroblasts, such as adipocytes and adipocyte-like cells, might play an important role in the pathogenic response to SARS-CoV-2 infection [84]. Expression of ACE2 is upregulated in the adipocytes of patients with DM, which renders adipose tissue a potential viral reservoir [68]. This may explain why patients with DM are at a high risk of contracting COVID-19 [68]. Furthermore, pulmonary lipofibroblasts located in the lung interstitium can transdifferentiate into myofibroblasts that play an integral part of pulmonary fibrosis [84]. An in vitro study reported that low concentrations of vitamin D was linked to adipocyte differentiation by the MAPK signaling pathway [85]. Vitamin $\mathrm{D}$ acts to inhibit apoptosis of adipocytes by reducing expression of the mitochondrial uncoupling protein 2 [86]. Mitochondrial dysfunction caused by vitamin D deficiency is particularly critical in debilitated conditions because it decreases adenosine triphosphate formation and increases ROS generation [87], which might be crucial for COVID-19. In addition, vitamin D regulates the expression of adiponectin, which has insulin-sensitizing and anti-inflammatory actions [88]. Taken together, alterations in cellular and systemic systems caused by vitamin D deficiency might impair mitochondrial function, contributing to the progression and severity of COVID-19 [89].
Uncontrolled glycemic status at admission and during a hospital stay are associated with worse clinical outcomes in patients with COVID-19 [90-92]. In turn, COVID-19 predisposes infected individuals to hyperglycemia [93]. Improving glycemic control in patients presenting with hyperglycemia with the assistance of vitamin D supplementation might help in reducing the risk of life-threatening metabolic complications.

\subsection{Vitamin D and cardiovascular and thromboembolic risks}

Vitamin D insufficiency is associated with increased cardiovascular disease (CVD) and thromboembolic risks [94, 95]. Animal and human studies suggest that serum $25(\mathrm{OH})$ D concentrations are inversely correlated with the prevalence of hypertension [96, 97]. High serum concentrations of $25(\mathrm{OH}) \mathrm{D}$ are considered to suppress renin formation in juxtaglomerular cells [98]. We found that participants with low $25(\mathrm{OH}) \mathrm{D}$ concentrations had a higher risk of significant coronary artery stenosis (odds ratio (OR) 2.1 for $25(\mathrm{OH}) \mathrm{D}$ concentrations of $15-29.9 \mathrm{ng} / \mathrm{mL}$ and 3.1 for $<15 \mathrm{ng} / \mathrm{mL}$ vs. at least $30 \mathrm{ng} / \mathrm{mL}$, respectively; both $P<0.05$ ) [95]. Of note, patients with DM and low vitamin D concentrations, as defined by a $25(\mathrm{OH}) \mathrm{D}$ concentration of $\leq 20 \mathrm{ng} / \mathrm{mL}$, showed a worse outcome after myocardial infarction [99]. One study found that both total $25(\mathrm{OH}) \mathrm{D}$ and its metabolites were associated with cardiovascular risk factors in patients with type 2 DM [94]. However, in the VITAL study, vitamin D supplementation did not result in a lower incidence of adverse cardiovascular events than did placebo [100]. However, it should be noted that only $12.7 \%$ of the participants in the VITAL study were vitamin D deficient at baseline [101].

Of note, vitamin D deficiency/insufficiency is associated with an increased risk of stroke. The neuroprotective mechanisms by which vitamin $\mathrm{D}$ operates to mitigate stroke onset and outcomes have yet to be fully elucidated. However, several pathways, including the production of certain neuroprotective growth factors, reduction of arterial pressure through vasodilation, and inhibition of ROS, can be involved [102].

Thrombotic complications are a common and major cause of death among patients with COVID-19 [103]. Intriguingly, vitamin $\mathrm{D}$ is also involved in the regulation of thrombotic pathways, and vitamin D insufficiency/deficiency is associated with an increase in thrombotic episodes [104]. Clearly, the protective effect of vitamin D supplementation on thrombosis should be investigated.

\subsection{Association between vitamin D and respiratory infection}

In a study using the US National Health and Nutritional Examination Survey data, serum 25(OH)D concentrations 


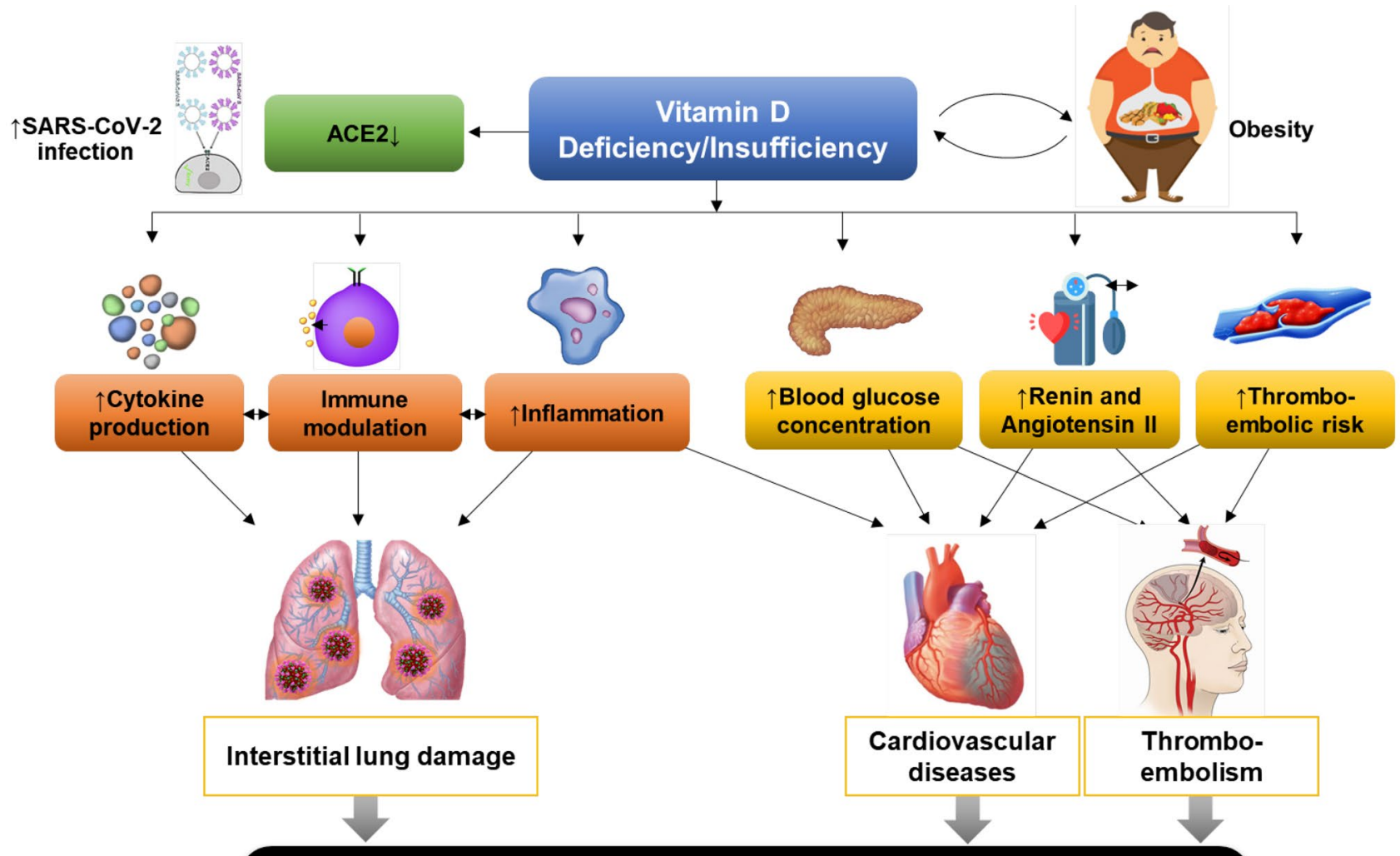

Multi-organ failure and increased mortality

Fig. 1 Proposed pathogenic mechanisms leading to severe COVID19 outcomes in individuals with vitamin D deficiency or insufficiency. ACE2, angiotensin-converting enzyme 2; COVID-19, coronavirus disease 2019; SARS-CoV-2, severe acute respiratory syndrome

were inversely associated with recent respiratory tract infection [105]. This association seemed to be stronger in individuals with asthma and chronic obstructive pulmonary disease [105]. In a prospective cohort study, maintenance of serum $25(\mathrm{OH}) \mathrm{D}$ concentrations $\geq 38 \mathrm{ng} / \mathrm{mL}$ significantly reduced the incidence of acute viral respiratory tract infection in healthy individuals [106]. It has also been proposed that vitamin D deficiency might contribute to the development of seasonal influenza [107]. Proposed pathogenic mechanisms triggered by SARS-CoV-2 infection, leading to severe morbidity and mortality, in individuals with vitamin D deficiency/insufficiency are shown in Fig. 1.

\subsection{Efficacy of vitamin D supplementation against respiratory infection}

Vitamin D supplementation might play a beneficial role in combatting respiratory infections. In school children, vitamin $\mathrm{D}$ supplementation during the winter showed a $42 \%$ reduction in the incidence of influenza $\mathrm{A}$, with a decrease in acute exacerbations of asthma, compared coronavirus 2. References for evidence: cytokine production [41]; immune modulation [18, 29]; inflammation [53]; blood glucose concentration [149]; renin and angiotensin II levels [64]; and thromboembolic risk [104]

with placebo [108]. A meta-analysis of RCTs with individual participant data found that vitamin D supplementation reduced the risk of acute respiratory tract infection compared with placebo (adjusted OR 0.88 ; 95\% CI 0.81-0.96) [109]. These protective effects were greater in those with vitamin $\mathrm{D}$ concentrations $<25 \mathrm{nmol} / \mathrm{L}$ (10 ng/mL; adjusted OR 0.30; 95\% CI 0.17-0.53) than in those with $\geq 25 \mathrm{nmol} / \mathrm{L}$ (adjusted OR $0.75 ; 95 \% \mathrm{CI}$ 0.80-1.20). A recent update of this meta-analysis, including 46 RCTs (75,541 participants), also showed protective effects of vitamin D administration with daily doses of 400-1000 IU for up to 12 months on acute respiratory infections [110]. In patients with active pulmonary tuberculosis, vitamin D supplementation increased the culture conversion rates and improved radiographic findings [111]. In another meta-analysis using individual participant data, vitamin D supplementation protected against acute respiratory infections, particularly in vitamin $\mathrm{D}$ deficient individuals and those not receiving bolus doses [112]. In a meta-analysis of nine trials involving 435 children and 658 adults, administration of vitamin 
$D$ reduced both the risk of severe asthma exacerbation and healthcare use [113]. However, several RCTs have reported conflicting results. In healthy individuals, administration of vitamin D (100,000 IU monthly) did not reduce the incidence or severity of upper respiratory tract infection [114]. High-dose supplementation with vitamin $\mathrm{D}$ did not prevent acute respiratory infections in older adults [115] or pneumonia in infants [116]. In 2021, the US Preventive Services Task Force reported that among community-dwelling populations with low vitamin D concentrations, treatment with vitamin $\mathrm{D}$ has no effect on mortality or the incidence of fractures, falls, depression, DM, CVD, cancer, or adverse events [117]. Overall, most but not all data support a role for vitamin D supplementation to prevent acute respiratory tract infections, especially in individuals with serum $25(\mathrm{OH}) \mathrm{D}$ concentrations $<10 \mathrm{ng} / \mathrm{mL}$ [110].

\section{Effects of vitamin D supplementation on SARS-CoV-2 infection}

The effects of vitamin D supplementation on acute respiratory tract infections, chronic lung disease, DM, and CVD are listed in Supplementary Table S1. Vitamin D deficiency is highly prevalent in patients hospitalized for COVID-19 [118]. Therefore, it is rational to anticipate the beneficial role of vitamin $\mathrm{D}$ supplementation in preventing this disease, reducing symptoms, or improving prognosis. Currently, more than 50 interventional studies are registered at ClinicalTrial.gov to investigate the effect of vitamin D on COVID-19. Among them, a few have found promising results (Table 1). In a pilot RCT, including 76 patients hospitalized for COVID19 , oral administration of high-dose calcifediol reduced ICU admissions. Concerns about the benefits of calcifediol administration have been raised because of imperfect blinding and uneven distribution of confounders [119]. An RCT of the oral administration of vitamin D3 (cholecalciferol; 60,000 IU daily), with a therapeutic target of serum $25(\mathrm{OH})$ $\mathrm{D}>50 \mathrm{ng} / \mathrm{mL}$, found that it significantly induced negative conversions of SARS-CoV-2-RNA and caused a decrease in fibrinogen [17]. Two quasi-experimental studies showed that vitamin D supplementation during or in the preceding month of SARS-CoV-2 infections was associated with less severe outcomes, including mortality, in frail elderly patients with COVID-19 [120, 121]. An RCT that gave vitamin D supplements to asymptomatic or mildly symptomatic patients with COVID-19 demonstrated amelioration of associated symptoms at day 14, although it did not significantly reduce the time for the negative conversion of the SARS-CoV-2 RNA virus [122]. In another RCT, a single high dose of vitamin D (200,000 IU) did not reduce hospital length of stay, mortality, ICU admission rates, or the need for mechanical ventilation in patients hospitalized for moderate-to-severe COVID-19 [123]. A recent meta-analysis found that $25(\mathrm{OH}) \mathrm{D}$ concentrations were weakly associated with COVID-19 severity when the threshold of $25(\mathrm{OH}) \mathrm{D}$ was set to $20 \mathrm{ng} / \mathrm{mL}$ [124]. In that study, thorough sensitivity analysis revealed a connection between a $25(\mathrm{OH}) \mathrm{D}$ concentration of $<30 \mathrm{ng} / \mathrm{mL}$ and increased mortality from COVID-19 [124].

Of note, we have conducted a meta-analysis with RCT data and found a positive impact of vitamin D supplementation on SARS-CoV-2 RNA positivity in asymptomatic or mildly symptomatic patients with COVID-19 [17, 122], but not in all-cause mortality or ICU admission in patients with moderate-to-severe COVID-19 [16, 125] (Fig. 2). The potential effects of optimum levels of vitamin D on critical pathways involved in the progress of COVID-19 are shown in Fig. 3.

\section{Caveats in the interpretation of data on vitamin D and COVID-19}

The role of vitamin D in the prevention and treatment of COVID-19 remains controversial. Several points should be considered to clarify this issue. Associations between vitamin D deficiency and the risk of SARS-CoV-2 infection or severe COVID-19 have been found in epidemiological studies [7, 56, 126-128], but several reports showed inconsistent results (Table 1). A retrospective study from the UK Biobank showed that both circulating $25(\mathrm{OH}) \mathrm{D}$ concentrations and vitamin $\mathrm{D}$ deficiency were not associated with the risk of COVID-19 [129]. In a retrospective case-control study, although $82.2 \%$ of hospitalized patients with COVID-19 had vitamin D deficiency, no relationship was found between serum $25(\mathrm{OH})$ D concentrations or vitamin D deficiency and severe outcomes [130]. A multicenter prospective cohort study showed that vitamin D deficient $(25(\mathrm{OH}) \mathrm{D}<10 \mathrm{mg} / \mathrm{mL})$ patients hospitalized for moderate-to-severe COVID-19 tended to have a longer hospital stay compared with patients with higher $25(\mathrm{OH}) \mathrm{D}$ concentrations, with no significant association with invasive mechanical ventilation or mortality rates [131]. However, most of these studies used historic $25(\mathrm{OH}) \mathrm{D}$ measurements or did not evaluate vitamin D status at the time of SARS-CoV-2 infection. Moreover, unmeasured or residual confounders might influence vitamin D deficiency, as independent risk factors for COVID-19.

One RCT showed that oral administration of a single high dose of vitamin D after diagnosis of COVID-19 did not reduce the hospital length of stay or improve clinical outcomes in hospitalized patients with moderate-to-severe COVID-19 [123]. This observation is not unexpected because the virus takes hold and initiates its damaging 
(A)

\begin{tabular}{lrr} 
& \multicolumn{2}{c}{ Vitamin D } \\
Study & Events & Total \\
Rastogi 2020 & 6 & 16 \\
Sanchez-Zuno 2021 & 0 & 22 \\
Total (95\% CI) & & \\
Heterogeneity: $I^{2}=0 \%, T^{2}=0, p=0.78$ &
\end{tabular}

(B)

\begin{tabular}{lrr} 
& \multicolumn{2}{c}{$\begin{array}{c}\text { Vitamin D } \\
\text { Events }\end{array}$} \\
Study & Total \\
Castillo 2020 & 0 & 50 \\
Murai 2021 & 9 & 119 \\
Total (95\% CI) & & $\mathbf{1 6 9}$ \\
Heterogeneity: $I^{2}=64 \%$, & $T^{2}=2.3065, p=0.10$
\end{tabular}

(C)

\begin{tabular}{lrr} 
& \multicolumn{2}{c}{ Vitamin D } \\
Study & Events & Total \\
Castillo 2020 & 1 & 50 \\
Murai 2021 & 19 & 119 \\
Total (95\% CI) \\
Heterogeneity: $I^{2}=89 \%, T^{2}=4.3748, p<0.01$
\end{tabular}

Fig. 2 The effects of vitamin D supplementation on (A) SARS-CoV-2 RNA positivity in asymptomatic or mildly symptomatic patients with COVID-19 [17, 122] and (B) all-cause mortality [16, 125] or (C) ICU admission [16, 125] in moderate-to-severe COVID-19 patients.

consequences on the respiratory epithelium and an exaggerated immune response, leading to a cytokine storm [123]. A recent Mendelian randomization study also failed to show the protective role of vitamin D supplementation in terms of COVID-19 susceptibility [132]. Thus, the evidence is very limited on the role of vitamin D treatment and how it can be involved in preventing or mitigating the development of COVID-19 and its clinical outcomes.

Studies linking vitamin D status with the degree of SARS-CoV-2 infectivity have suggested a significant inverse relationship between them, along with the modulation of the immune system. Although there are some reports that do not advocate vitamin $\mathrm{D}$ supplementation over placebo [100, 133-135], it would be prudent to correct vitamin $\mathrm{D}$ deficiency/insufficiency not only in patients with COVID-19 but in all individuals to reduce the risk for many acute and chronic illnesses.

Despite possible synergistic effects on immunomodulation and anti-inflammation [136, 137], the relationship
Risk Ratio (RR)

M-H, Random, 95\% CI $\quad$ RR $\quad 95 \%$ CI Weight

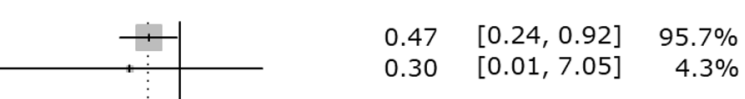

$0.46[0.24,0.89] 100.0 \%$

$0.1 \quad 0.512 \quad 10$

Favor vitamin D Favor placebo or standard care alone

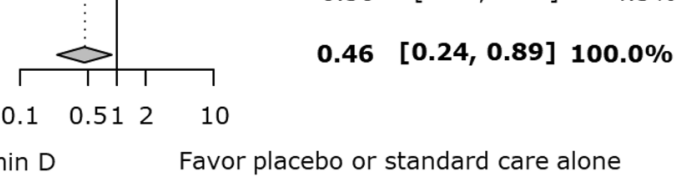

Risk Ratio (RR)

M-H, Random, 95\% CI

RR $\quad 95 \%$ CI Weight

$0.10 \quad[0.01,2.11] \quad 35.6 \%$

$1.49[0.55,4.05] \quad 64.4 \%$

$0.58[0.05,7.20] 100.0 \%$
Favor vitamin D Favor placebo or standard care alone
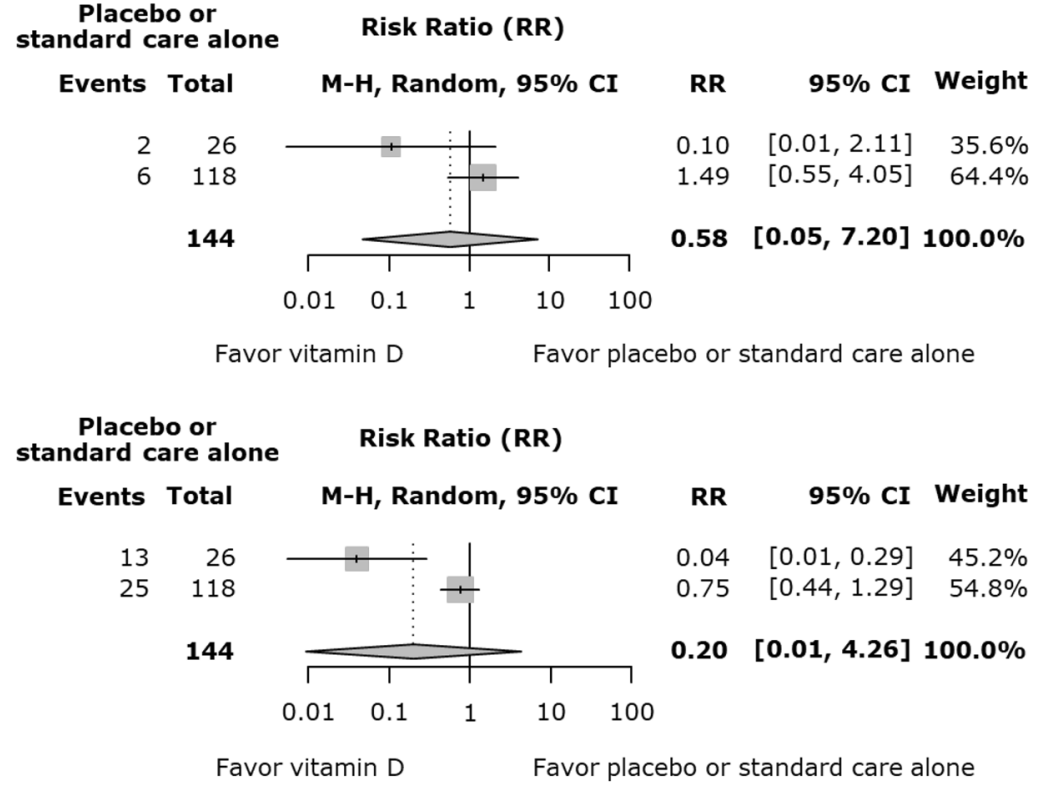

COVID-19, coronavirus disease 2019; SARS-CoV-2, severe acute respiratory syndrome coronavirus 2; CI, confidence interval; ICU, intensive care unit; M-H, Mantel-Haenszel method

between vitamin D and COVID-19 therapies, such as remdesivir, monoclonal antibodies (casirivimab/imdevimab, sotrovimab, and bamlanivimab/etesevimab), and immune modulators (baricitinib and tocilizumab), has not yet been evaluated (see https://www.idsociety.org/practice-guideline/ covid-19-guideline-treatment-and-management/. Accessed 24 November 2021). Medications, such as dexamethasone, can complicate the effects of vitamin D supplementation in patients with COVID-19 [138]. Whether improving vitamin D status in symptomatic and asymptomatic patients with COVID-19 reduces the risk for long-term sequelae from COVID-19 (long COVID or post-acute COVID syndrome) also remains unknown.

COVID-19 vaccination programs have been initiated widely [139]. Interestingly, vitamin D supplementation promoted TGF- $\beta$ levels in response to influenza vaccination in elderly individuals with vitamin D deficiency [140]. These effects were accompanied by changes in the degree of lymphocyte polarization towards a tolerogenic immune 


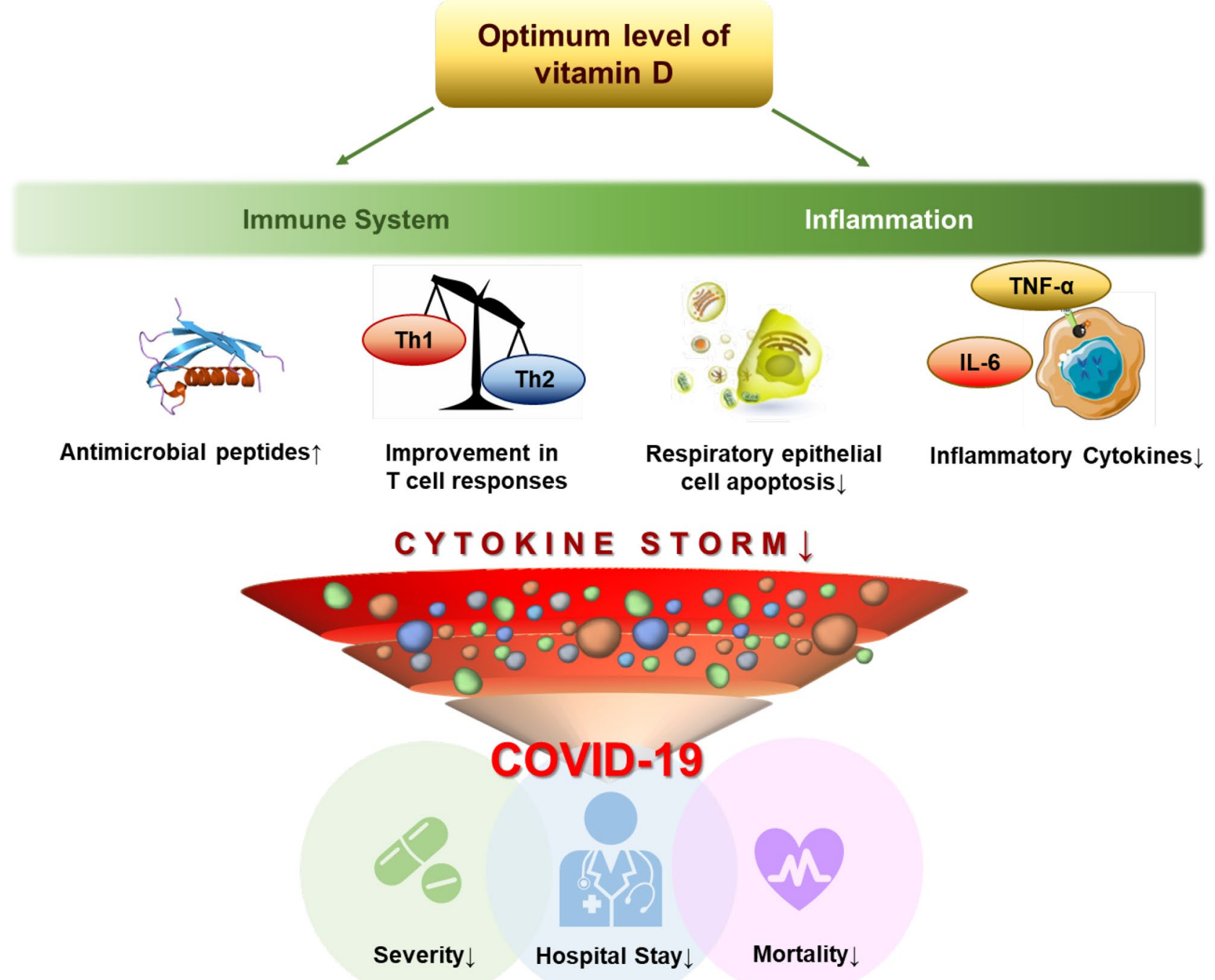

Fig. 3 Potential effects of optimum levels of vitamin D on critical pathways involved in the progress of COVID-19. COVID-19, coronavirus disease 2019; IL-6, interleukin-6; Th1, type 1 helper T cell; Th2, type 2 helper T cell; TNF- $\alpha$, tumor necrosis factor- $\alpha$. References

response [140]. Improvement in vitamin D status might also enhance immunity associated with vaccination [29]. Thus, vitamin D status might affect the immune response to vaccines against COVID-19. Further studies regarding vitamin $\mathrm{D}$ status and vaccination efficacy are warranted.

\section{Practical considerations in vitamin D supplementation against COVID-19}

To date, there are no consensus guidelines suggesting an adequate concentration of serum $25(\mathrm{OH}) \mathrm{D}$ in preventing COVID-19 or in reducing its morbidity and mortality. However, based on the available data, it is prudent to aim at for evidence: antimicrobial peptides [36]; T cell responses [43]; apoptosis of infected respiratory epithelial cells [150]; and inflammatory cytokines [58]

vitamin D sufficiency with a serum concentration of $25(\mathrm{OH})$ D of at least $30 \mathrm{ng} / \mathrm{mL}$ with a preferred range of $40-60 \mathrm{ng} /$ $\mathrm{mL}$ as recommended by the Endocrine Society's Practice Guidelines on Vitamin D [1].

In modern societies, it is difficult to obtain an adequate amount of vitamin D from sun exposure daily. It has been reported that a normal weight adult in a bathing suit exposed to one minimal erythema dose (which is defined as the amount of sunlight that causes a slight pinkness to skin in 24 hours) produces an amount of vitamin D that is equivalent to ingesting between 10,000 and 20,000 IU [141]. Time of day, season, latitude, weather conditions, altitude, and skin pigmentation all influence the effectiveness of the sun in producing vitamin $\mathrm{D}$ in the skin. 
Similarly, proper sunscreen with a sun protection factor of 30 reduces the efficiency of sun exposure to produce vitamin D in the skin by more than $97 \%$ [141]. The preventive measures against the COVID-19 outbreak implemented in many countries include recommending social distancing, telecommuting, remote class activities, and closure of exercise facilities. These measures are likely to contribute to vitamin D deficiency/insufficiency in the general public.

To prevent vitamin D deficiency, we propose following the Endocrine Society's Practice Guidelines on Vitamin D [1]. To treat vitamin D deficiency, 50,000 IU of weekly vitamin $\mathrm{D}$ (equivalent to $\sim 6,600 \mathrm{IU}$ daily) for 8 weeks was shown to be effective in raising serum $25(\mathrm{OH}) \mathrm{D}$ concentrations above $30 \mathrm{ng} / \mathrm{mL}$ without any untoward toxicity [142]. In the Short Term, High-Dose Vitamin D Supplementation for COVID-19 (SHADE) study, an RCT in which 60,000 IU of oral vitamin D3 was provided in the intervention arm, $75 \%$ of the patients with COVID-19 achieved a $25(\mathrm{OH}) \mathrm{D}$ concentration of $>50 \mathrm{ng} / \mathrm{mL}$ by day 14 [17]. In that study, fibrinogen levels in patients who attained this status were significantly lower than in those with vitamin D deficiency, implying that adequate serum 25(OH)D concentrations might exert antithrombotic effects.

To maintain vitamin D sufficiency, the Endocrine Society recommends 400-1,000, 600-1,000, and 1,500-2,000 IU of vitamin D2 or vitamin D3 daily for infants aged up to 1 year, children, and adults aged $\geq 18$ years, respectively [1]. For those patients hospitalized with moderate COVID-19, rapid augmentation with $25(\mathrm{OH}) \mathrm{D}$ is imperative when the patient is found to be vitamin D deficient or insufficient. This can be achieved by giving pharmacological doses of vitamin $\mathrm{D}$ in the range of 50,000-100,000 IU on admission. It has been demonstrated that $50,000 \mathrm{IU}$ of vitamin $\mathrm{D}$ given once every 2 weeks (equivalent to approximately 3,300 IU daily) is effective for up to 6 years in maintaining circulating concentrations of $25(\mathrm{OH}) \mathrm{D}$ in the preferred range of $40-60 \mathrm{ng} / \mathrm{mL}$ [1]. However, obese adults need 2-3 times more vitamin D to satisfy their requirement because of the dilutional effect of the fat-soluble vitamin $\mathrm{D}$ in the large body fat reservoir. Under such circumstances, we advocate a loading dose of $10,000 \mathrm{IU}$, followed by a maintenance dosage of 3,200-4,000 IU daily as used in an ongoing trial of Vitamin D for COVID-19 (VIVID) [143].

Oral vitamin D supplementation is generally preferred to intramuscular injection. Intravenous administration of vitamin $\mathrm{D}$ is usually not recommended because of variable bioavailability. However, parenteral administration of vitamin D might be necessary for severely affected patients admitted to an ICU. Considering the minimal harm and potential benefits of vitamin D supplementation, an oral dosage of 50,000 IU daily or an intramuscular dosage of 100,000-200,000 IU daily could prove advantageous. This recommendation of the oral dosage is based on a prospective study that demonstrated that administration of 50,000 IU of vitamin D for 10 days effectively and rapidly normalized serum $25(\mathrm{OH}) \mathrm{D}$ concentrations in vitamin $\mathrm{D}$ deficient individuals without notable adverse events [144]. A systematic review suggested that 200,000-600,000 IU as a single oral dose was effective in raising circulating concentrations of $25(\mathrm{OH}) \mathrm{D}$ to $>30 \mathrm{ng} /$ $\mathrm{mL}$ [145]. Transient hypercalciuria was observed in some patients who received $600,000 \mathrm{IU}$, but no other untoward toxicity was observed at any of these doses [145].

We do not recommend giving patients $1,25(\mathrm{OH})_{2} \mathrm{D} 3$ (calcitriol) to treat vitamin D deficiency. Not only does this hormone have a very short half-life $(\sim 4 \mathrm{~h})$, but it can cause a marked increase in intestinal calcium absorption, resulting in transient hypercalciuria and hypercalcemia. Animal studies have also demonstrated that $1,25(\mathrm{OH})_{2} \mathrm{D} 3$ can cause vascular calcification [146, 147]. The dosing interval might be critical in vitamin D supplementation for patients with COVID-19. A systematic review and meta-analysis of individual participant data from 25 RCTs concluded that vitamin D supplementation was safe and provided modest protection against acute respiratory tract infections (adjusted OR 0.88; 95\% CI 0.81-0.96) [109]. Notably, a subgroup analysis showed that beneficial effects were observed in patients receiving daily or weekly doses (adjusted OR 0.81; 95\% CI 0.72-0.91), but not in those receiving a single bolus dose (adjusted OR 0.97 ; $95 \%$ CI $0.86-1.10$ ). These findings were consistently observed in the recently published update of this study [110].

\section{Conclusions}

There is now substantial evidence suggesting a significant association between vitamin D insufficiency/deficiency and COVID-19 susceptibility and its severity. Several RCTs have suggested the beneficial effects of vitamin D supplementation on ameliorating respiratory infections and COVID-19, although its efficacy was rather modest. Targeting the host's metabolism might be a viable strategy to protect against pathogenic signals induced during SARS-CoV-2 infection and to limit tissue susceptibility to damage signals [148]. Based on this evidence, it is advisable to avoid vitamin D deficiency in the general population to maximize innate and adaptive immunity [19] and prevent adverse cardiovascular outcomes [27], particularly during the COVID-19 pandemic. Current evidence suggests that taking a vitamin D supplement at doses recommended by the Endocrine Society to maintain a serum concentration of $25(\mathrm{OH}) \mathrm{D}$ of at least $30 \mathrm{ng} / \mathrm{mL}$ 


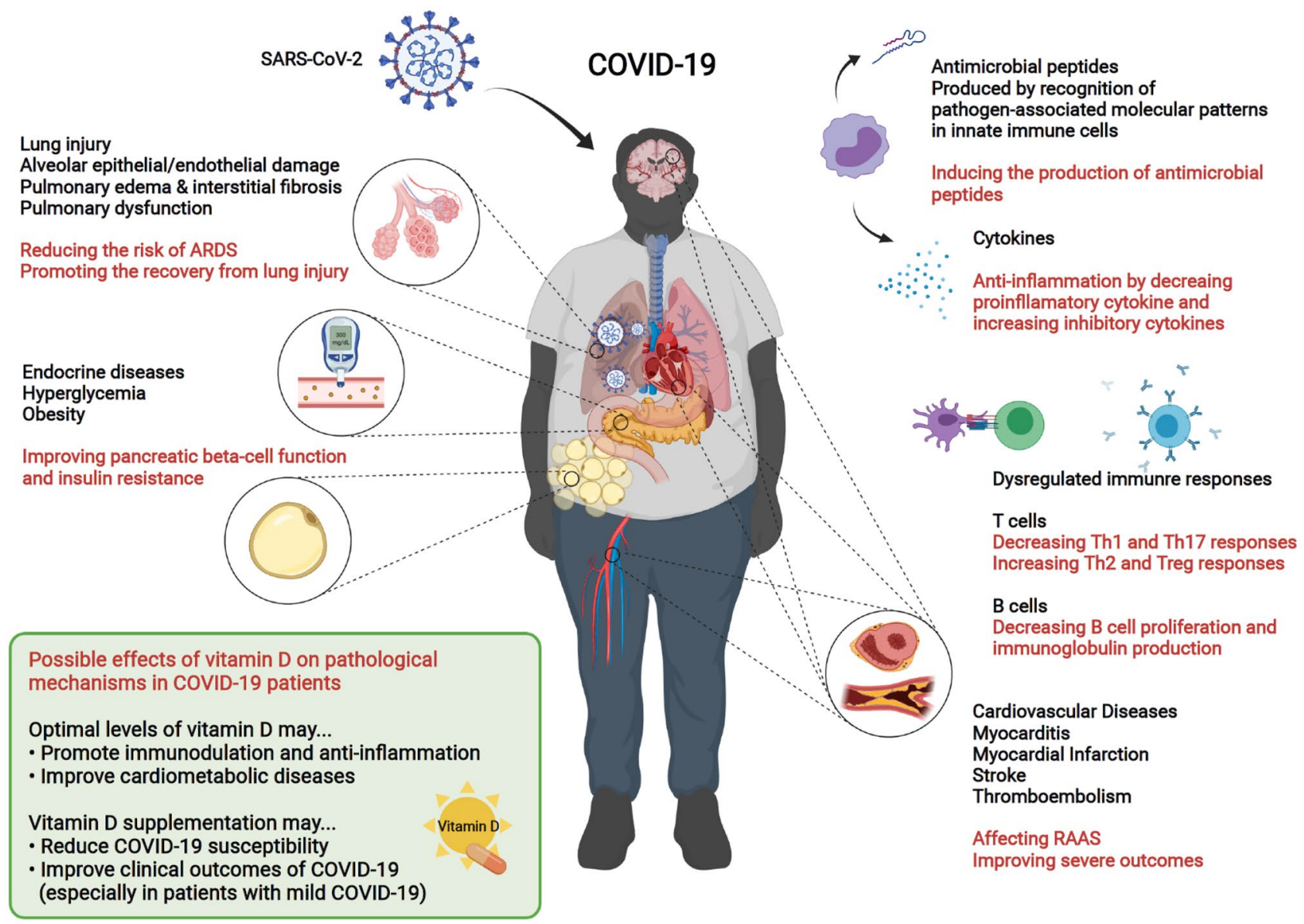

Fig. 4 Impacts of SARS-CoV-2 infection on human biological systems and proposed favorable effects of vitamin D on pathogenic processes involved in COVID-19. ARDS, acute respiratory distress syndrome; COVID-19, coronavirus disease 2019; RAAS, renin-

can help reduce the risk of SARS-CoV-2 infection and its severe outcomes, including mortality (Fig. 4). Ongoing well-designed interventional studies should provide conclusive information on the effects of vitamin D supplementation on the prevention and treatment of COVID-19 (Supplementary Table S2).

Supplementary Information The online version contains supplementary material available at https://doi.org/10.1007/s11154-021-09705-6.

Authors' contributions J.H.B. and H.J.C. conceived and designed the review, researched the literature, and wrote the manuscript. S.L. and M.F.H. reviewed, edited the manuscript, and were responsible for supervision. All authors read and approved the final manuscript.

Funding Not applicable.

Data availability Not applicable.

Code availability Not applicable. angiotensin-aldosterone system; SARS-CoV-2, severe acute respiratory syndrome coronavirus 2 ; Th1, type 1 helper T cell; Th2, type 2 helper T cell; Th17, type 17 helper T cell; Treg, regulatory $\mathrm{T}$ cell

\section{Declarations}

Ethics approval Not applicable.

Consent to participate Not applicable.

Consent for publication Not applicable.

Conflict of interest The authors declare no competing interests.

\section{References}

1. Holick MF, Binkley NC, Bischoff-Ferrari HA, Gordon CM, Hanley DA, Heaney RP, et al. Evaluation, treatment, and prevention of vitamin D deficiency: an Endocrine Society clinical practice guideline. J Clin Endocrinol Metab. 2011;96:1911-30.

2. Cashman KD, Vitamin D. Deficiency: Defining, Prevalence, Causes, and Strategies of Addressing. Calcif Tissue Int. 2020;106:14-29. 
3. Hilger J, Friedel A, Herr R, Rausch T, Roos F, Wahl DA, et al. A systematic review of vitamin $\mathrm{D}$ status in populations worldwide. Br J Nutr. 2014;111:23-45.

4. van der Wielen RP, Lowik MR, van den Berg H, de Groot LC, Haller J, Moreiras O, et al. Serum vitamin D concentrations among elderly people in Europe. Lancet. 1995;346:207-10.

5. Laird E, O'Halloran AM, Carey D, Healy M, O'Connor D, Moore P, et al. The Prevalence of Vitamin D Deficiency and the Determinants of $25(\mathrm{OH}) \mathrm{D}$ Concentration in Older Irish Adults: Data From The Irish Longitudinal Study on Ageing (TILDA). J Gerontol A Biol Sci Med Sci. 2018;73:519-25.

6. Kaufman HW, Niles JK, Kroll MH, Bi C, Holick MF. SARS-CoV-2 positivity rates associated with circulating 25 -hydroxyvitamin $\mathrm{D}$ levels. PLoS One. 2020;15:e0239252.

7. Meltzer DO, Best TJ, Zhang H, Vokes T, Arora V, Solway J. Association of Vitamin D Status and Other Clinical Characteristics With COVID-19 Test Results. JAMA Netw Open. 2020;3:e2019722.

8. Kohlmeier M. Avoidance of vitamin D deficiency to slow the COVID-19 pandemic. BMJ Nutrition, Prevention \& Health. 2020;3:e000096.

9. Public Health England. Beyond the data: Understanding the impact of COVID-19 on BAME groups. London, UK2020.

10. Rhodes JM, Subramanian S, Laird E, Griffin G, Kenny RA. Perspective: Vitamin D deficiency and COVID-19 severity plausibly linked by latitude, ethnicity, impacts on cytokines, ACE2 and thrombosis. J Intern Med. 2020.

11. Williamson EJ, Walker AJ, Bhaskaran K, Bacon S, Bates C, Morton CE, et al. Factors associated with COVID-19-related death using OpenSAFELY. Nature. 2020;584:430-6.

12. Merzon E, Tworowski D, Gorohovski A, Vinker S, Golan Cohen A, Green I, et al. Low plasma 25(OH) vitamin D level is associated with increased risk of COVID-19 infection: an Israeli population-based study. FEBS J. 2020;287:3693-702.

13. Radujkovic A, Hippchen T, Tiwari-Heckler S, Dreher S, Boxberger M, Merle U. Vitamin D Deficiency and Outcome of COVID-19 Patients. Nutrients. 2020;12.

14. De Smet D, De Smet K, Herroelen P, Gryspeerdt S, Martens GA. Serum 25(OH)D Level on Hospital Admission Associated With COVID-19 Stage and Mortality. Am J Clin Pathol. 2021;155:381-8.

15. Benskin LL. A Basic Review of the Preliminary Evidence That COVID-19 Risk and Severity Is Increased in Vitamin D Deficiency. Front Public Health. 2020;8:513.

16. Entrenas Castillo M, Entrenas Costa LM, Vaquero Barrios JM, Alcala Diaz JF, Lopez Miranda J, Bouillon R, et al. "Effect of calcifediol treatment and best available therapy versus best available therapy on intensive care unit admission and mortality among patients hospitalized for COVID-19: A pilot randomized clinical study". J Steroid Biochem Mol Biol. 2020;203:105751.

17. Rastogi A, Bhansali A, Khare N, Suri V, Yaddanapudi N, Sachdeva N, et al. Short term, high-dose vitamin D supplementation for COVID19 disease: a randomised, placebo-controlled, study (SHADE study). Postgrad Med J. 2020.

18. Tay MZ, Poh CM, Renia L, MacAry PA, Ng LFP. The trinity of COVID-19: immunity, inflammation and intervention. Nat Rev Immunol. 2020;20:363-74.

19. Charoenngam N, Holick MF. Immunologic Effects of Vitamin D on Human Health and Disease. Nutrients. 2020;12.

20. Beard JA, Bearden A, Striker R. Vitamin D and the anti-viral state. J Clin Virol. 2011;50:194-200.

21. Xu J, Yang J, Chen J, Luo Q, Zhang Q, Zhang H. Vitamin $\mathrm{D}$ alleviates lipopolysaccharideinduced acute lung injury via regulation of the reninangiotensin system. Mol Med Rep. 2017;16:7432-8.
22. Cui C, Xu P, Li G, Qiao Y, Han W, Geng C, et al. Vitamin D receptor activation regulates microglia polarization and oxidative stress in spontaneously hypertensive rats and angiotensin II-exposed microglial cells: Role of renin-angiotensin system. Redox Biol. 2019;26:101295.

23. Grant WB, Lahore H, McDonnell SL, Baggerly CA, French $\mathrm{CB}$, Aliano JL, et al. Evidence that Vitamin D Supplementation Could Reduce Risk of Influenza and COVID-19 Infections and Deaths. Nutrients. 2020;12.

24. Gunville CF, Mourani PM, Ginde AA. The role of vitamin D in prevention and treatment of infection. Inflamm Allergy Drug Targets. 2013;12:239-45.

25. Girgis CM, Clifton-Bligh RJ, Hamrick MW, Holick MF, Gunton JE. The roles of vitamin D in skeletal muscle: form, function, and metabolism. Endocr Rev. 2013;34:33-83.

26. Vanherwegen AS, Gysemans C, Mathieu C. Regulation of Immune Function by Vitamin D and Its Use in Diseases of Immunity. Endocrinol Metab Clin North Am. 2017;46:1061-94.

27. Bouillon R, Marcocci C, Carmeliet G, Bikle D, White JH, Dawson-Hughes B, et al. Skeletal and Extraskeletal Actions of Vitamin D: Current Evidence and Outstanding Questions. Endocr Rev. 2019;40:1109-51.

28. Mora JR, Iwata M, von Andrian UH. Vitamin effects on the immune system: vitamins A and D take centre stage. Nat Rev Immunol. 2008;8:685-98.

29. Vanherwegen AS, Gysemans C, Mathieu C. Vitamin D endocrinology on the cross-road between immunity and metabolism. Mol Cell Endocrinol. 2017;453:52-67.

30. Laplana M, Royo JL, Fibla J. Vitamin D Receptor polymorphisms and risk of enveloped virus infection: A meta-analysis. Gene. 2018;678:384-94.

31. Evans RM, Lippman SM. Shining Light on the COVID-19 Pandemic: A Vitamin D Receptor Checkpoint in Defense of Unregulated Wound Healing. Cell Metab. 2020;32:704-9.

32. Ding N, Yu RT, Subramaniam N, Sherman MH, Wilson C, Rao $\mathrm{R}$, et al. A vitamin D receptor/SMAD genomic circuit gates hepatic fibrotic response. Cell. 2013;153:601-13.

33. Taheri M, Rad LM, Hussen BM, Nicknafs F, Sayad A, GhafouriFard S. Evaluation of expression of VDR-associated lncRNAs in COVID-19 patients. BMC Infect Dis. 2021;21:588.

34. Pahar B, Madonna S, Das A, Albanesi C, Girolomoni G. Immunomodulatory Role of the Antimicrobial LL-37 Peptide in Autoimmune Diseases and Viral Infections. Vaccines (Basel). $2020 ; 8$.

35. Akira S, Uematsu S, Takeuchi O. Pathogen recognition and innate immunity. Cell. 2006;124:783-801.

36. White JH. Vitamin D as an inducer of cathelicidin antimicrobial peptide expression: past, present and future. J Steroid Biochem Mol Biol. 2010;121:234-8.

37. Wang TT, Nestel FP, Bourdeau V, Nagai Y, Wang Q, Liao $\mathrm{J}$, et al. Cutting edge: 1,25-dihydroxyvitamin D3 is a direct inducer of antimicrobial peptide gene expression. J Immunol. 2004;173:2909-12.

38. Yuk JM, Shin DM, Lee HM, Yang CS, Jin HS, Kim KK, et al. Vitamin D3 induces autophagy in human monocytes/macrophages via cathelicidin. Cell Host Microbe. 2009;6:231-43.

39. Zhang H, Zhao Y, Jiang X, Zhao Y, Li Y, Li C, et al. Preliminary evaluation of the safety and efficacy of oral human antimicrobial peptide LL-37 in the treatment of patients of COVID-19, a small-scale, single-arm, exploratory safety study. medRxiv. 2020:2020.05.11.20064584.

40. Weatherhead JE, Clark E, Vogel TP, Atmar RL, Kulkarni PA. Inflammatory syndromes associated with SARS-CoV-2 infection: dysregulation of the immune response across the age spectrum. J Clin Invest. 2020;130:6194-7. 
41. Fajgenbaum DC, June CH. Cytokine Storm. N Engl J Med. 2020;383:2255-73.

42. Vabret N, Britton GJ, Gruber C, Hegde S, Kim J, Kuksin M, et al. Immunology of COVID-19: Current State of the Science. Immunity. 2020;52:910-41.

43. Yang J, Zheng Y, Gou X, Pu K, Chen Z, Guo Q, et al. Prevalence of comorbidities and its effects in patients infected with SARSCoV-2: a systematic review and meta-analysis. Int J Infect Dis. 2020;94:91-5.

44. Fritsche J, Mondal K, Ehrnsperger A, Andreesen R, Kreutz M. Regulation of 25-hydroxyvitamin D3-1 alpha-hydroxylase and production of 1 alpha,25-dihydroxyvitamin D3 by human dendritic cells. Blood. 2003;102:3314-6.

45. Penna G, Adorini L. 1 Alpha, 25-dihydroxyvitamin D3 inhibits differentiation, maturation, activation, and survival of dendritic cells leading to impaired alloreactive $\mathrm{T}$ cell activation. J Immunol. 2000;164:2405-11.

46. Dankers W, Colin EM, van Hamburg JP, Lubberts E. Vitamin D in Autoimmunity: Molecular Mechanisms and Therapeutic Potential. Front Immunol. 2016;7:697.

47. Chauss D, Freiwald T, McGregor R, Yan B, Wang L, NovaLamperti E, et al. Autocrine vitamin D signaling switches off pro-inflammatory programs of TH1 cells. Nat Immunol. 2021.

48. Redlich K, Smolen JS. Inflammatory bone loss: pathogenesis and therapeutic intervention. Nat Rev Drug Discov. 2012;11:234-50.

49. Weitzmann MN, Ofotokun I. Physiological and pathophysiological bone turnover - role of the immune system. Nat Rev Endocrinol. 2016;12:518-32.

50. Obitsu S, Ahmed N, Nishitsuji H, Hasegawa A, Nakahama K, Morita I, et al. Potential enhancement of osteoclastogenesis by severe acute respiratory syndrome coronavirus $3 \mathrm{a} / \mathrm{X} 1$ protein. Arch Virol. 2009;154:1457-64.

51. Hardy RS, Zhou H, Seibel MJ, Cooper MS. Glucocorticoids and Bone: Consequences of Endogenous and Exogenous Excess and Replacement Therapy. Endocr Rev. 2018;39:519-48.

52. di Filippo L, Formenti AM, Doga M, Pedone E, Rovere-Querini P, Giustina A. Radiological Thoracic Vertebral Fractures are Highly Prevalent in COVID-19 and Predict Disease Outcomes. J Clin Endocrinol Metab. 2021;106:e602-14.

53. Lee S, Channappanavar R, Kanneganti TD. Coronaviruses: Innate Immunity, Inflammasome Activation, Inflammatory Cell Death, and Cytokines. Trends Immunol. 2020;41:1083-99.

54. Costela-Ruiz VJ, Illescas-Montes R, Puerta-Puerta JM, Ruiz C, Melguizo-Rodriguez L. SARS-CoV-2 infection: The role of cytokines in COVID-19 disease. Cytokine Growth Factor Rev. 2020;54:62-75.

55. Ahmadpoor P, Rostaing L. Why the immune system fails to mount an adaptive immune response to a COVID-19 infection. Transpl Int. 2020;33:824-5.

56. Jain A, Chaurasia R, Sengar NS, Singh M, Mahor S, Narain S. Analysis of vitamin D level among asymptomatic and critically ill COVID-19 patients and its correlation with inflammatory markers. Sci Rep. 2020;10:20191.

57. Daneshkhah A, Agrawal V, Eshein A, Subramanian H, Roy HK, Backman V. Evidence for possible association of vitamin $\mathrm{D}$ status with cytokine storm and unregulated inflammation in COVID-19 patients. Aging Clin Exp Res. 2020;32:2141-58.

58. Calton EK, Keane KN, Newsholme P, Soares MJ. The Impact of Vitamin D Levels on Inflammatory Status: A Systematic Review of Immune Cell Studies. PLoS One. 2015;10:e0141770.

59. Zhang Y, Leung DY, Richers BN, Liu Y, Remigio LK, Riches DW, et al. Vitamin D inhibits monocyte/macrophage proinflammatory cytokine production by targeting MAPK phosphatase-1. J Immunol. 2012;188:2127-35.

60. Wobke TK, Sorg BL, Steinhilber D. Vitamin D in inflammatory diseases. Front Physiol. 2014;5:244.
61. Zhang J, McCullough PA, Tecson KM. Vitamin D deficiency in association with endothelial dysfunction: Implications for patients with COVID-19. Rev Cardiovasc Med. 2020;21:339-44.

62. Group RC, Horby P, Lim WS, Emberson JR, Mafham M, Bell JL, et al. Dexamethasone in Hospitalized Patients with Covid-19. N Engl J Med. 2021;384:693-704.

63. Shoemark DK, Colenso CK, Toelzer C, Gupta K, Sessions RB, Davidson AD, et al. Molecular Simulations suggest Vitamins, Retinoids and Steroids as Ligands of the Free Fatty Acid Pocket of the SARS-CoV-2 Spike Protein*. Angew Chem Int Ed Engl. 2021;60:7098-110.

64. Brojakowska A, Narula J, Shimony R, Bander J. Clinical Implications of SARS-CoV-2 Interaction With Renin Angiotensin System: JACC Review Topic of the Week. J Am Coll Cardiol. 2020;75:3085-95.

65. Li YC, Kong J, Wei M, Chen ZF, Liu SQ, Cao LP. 1,25Dihydroxyvitamin $\mathrm{D}(3)$ is a negative endocrine regulator of the renin-angiotensin system. J Clin Invest. 2002;110:229-38.

66. Forman JP, Williams JS, Fisher ND. Plasma 25-hydroxyvitamin $\mathrm{D}$ and regulation of the renin-angiotensin system in humans. Hypertension. 2010;55:1283-8.

67. Nishiga M, Wang DW, Han Y, Lewis DB, Wu JC. COVID-19 and cardiovascular disease: from basic mechanisms to clinical perspectives. Nat Rev Cardiol. 2020;17:543-58.

68. Lim S, Bae JH, Kwon HS, Nauck MA. COVID-19 and diabetes mellitus: from pathophysiology to clinical management. Nat Rev Endocrinol. 2021;17:11-30.

69. Tomaschitz A, Pilz S, Ritz E, Grammer T, Drechsler C, Boehm BO, et al. Independent association between 1,25-dihydroxyvitamin D, 25-hydroxyvitamin D and the renin-angiotensin system: The Ludwigshafen Risk and Cardiovascular Health (LURIC) study. Clin Chim Acta. 2010;411:1354-60.

70. Shi Y, Liu T, Yao L, Xing Y, Zhao X, Fu J, et al. Chronic vitamin $D$ deficiency induces lung fibrosis through activation of the renin-angiotensin system. Sci Rep. 2017;7:3312.

71. Xiao D, Li X, Su X, Mu D, Qu Y. Could SARS-CoV-2-induced lung injury be attenuated by vitamin D? Int J Infect Dis. 2021;102:196-202.

72. Stefan N, Birkenfeld AL, Schulze MB. Global pandemics interconnected - obesity, impaired metabolic health and COVID-19. Nat Rev Endocrinol. 2021;17:135-49.

73. Drucker DJ. Coronavirus Infections and Type 2 Diabetes-Shared Pathways with Therapeutic Implications. Endocr Rev. 2020;41.

74. Holick MF. Vitamin D deficiency. N Engl J Med. 2007;357:266-81.

75. Norman AW. From vitamin D to hormone D: fundamentals of the vitamin D endocrine system essential for good health. Am J Clin Nutr. 2008;88:491S-S499.

76. Bourlon PM, Faure-Dussert A, Billaudel B. The de novo synthesis of numerous proteins is decreased during vitamin D3 deficiency and is gradually restored by 1,25-dihydroxyvitamin D3 repletion in the islets of langerhans of rats. J Endocrinol. 1999;162:101-9.

77. Ko SH, Lee GS, Vo TT, Jung EM, Choi KC, Cheung KW, et al. Dietary calcium and 1,25-dihydroxyvitamin D3 regulate transcription of calcium transporter genes in calbindin-D9k knockout mice. J Reprod Dev. 2009;55:137-42.

78. Xi Q, Wang S, Ye Z, Liu J, Yu X, Zhu Z, et al. Adenovirusdelivered microRNA targeting the vitamin $\mathrm{D}$ receptor reduces intracellular $\mathrm{Ca}(2)(+)$ concentrations by regulating the expression of $\mathrm{Ca}(2)(+)$-transport proteins in renal epithelial cells. BJU Int. 2011;107:1314-9.

79. Pittas AG, Lau J, Hu FB, Dawson-Hughes B. The role of vitamin $\mathrm{D}$ and calcium in type 2 diabetes. A systematic review and metaanalysis. J Clin Endocrinol Metab. 2007;92:2017-29.

80. Norman AW, Frankel JB, Heldt AM, Grodsky GM. Vitamin $\mathrm{D}$ deficiency inhibits pancreatic secretion of insulin. Science. 1980;209:823-5. 
81. Kayaniyil S, Vieth R, Retnakaran R, Knight JA, Qi Y, Gerstein $\mathrm{HC}$, et al. Association of vitamin $\mathrm{D}$ with insulin resistance and beta-cell dysfunction in subjects at risk for type 2 diabetes. Diabetes Care. 2010;33:1379-81.

82. Manson JE, Bassuk SS, Lee IM, Cook NR, Albert MA, Gordon D, et al. The VITamin D and OmegA-3 TriaL (VITAL): rationale and design of a large randomized controlled trial of vitamin $\mathrm{D}$ and marine omega-3 fatty acid supplements for the primary prevention of cancer and cardiovascular disease. Contemp Clin Trials. 2012;33:159-71.

83. Berridge MJ. Vitamin D deficiency and diabetes. Biochem J. 2017;474:1321-32.

84. Kruglikov IL, Scherer PE. The Role of Adipocytes and AdipocyteLike Cells in the Severity of COVID-19 Infections. Obesity (Silver Spring). 2020;28:1187-90.

85. Sakuma S, Fujisawa J, Sumida M, Tanigawa M, Inoda R, Sujihera $\mathrm{T}$, et al. The involvement of mitogen-activated protein kinases in the 1alpha,25-dihydroxy-cholecalciferol-induced inhibition of adipocyte differentiation in vitro. J Nutr Sci Vitaminol (Tokyo). 2012;58:1-8.

86. Sun X, Zemel MB. Role of uncoupling protein 2 (UCP2) expression and 1alpha, 25-dihydroxyvitamin D3 in modulating adipocyte apoptosis. FASEB J. 2004;18:1430-2.

87. Calton EK, Keane KN, Soares MJ. The potential regulatory role of vitamin $\mathrm{D}$ in the bioenergetics of inflammation. Curr Opin Clin Nutr Metab Care. 2015;18:367-73.

88. Abbas MA. Physiological functions of Vitamin D in adipose tissue. J Steroid Biochem Mol Biol. 2017;165:369-81.

89. Saleh J, Peyssonnaux C, Singh KK, Edeas M. Mitochondria and microbiota dysfunction in COVID-19 pathogenesis. Mitochondrion. 2020;54:1-7.

90. Scheen AJ, Marre M, Thivolet C. Prognostic factors in patients with diabetes hospitalized for COVID-19: Findings from the CORONADO study and other recent reports. Diabetes Metab. 2020;46:265-71.

91. Li H, Tian S, Chen T, Cui Z, Shi N, Zhong X, et al. Newly diagnosed diabetes is associated with a higher risk of mortality than known diabetes in hospitalized patients with COVID-19. Diabetes Obes Metab. 2020;22:1897-906.

92. Apicella M, Campopiano MC, Mantuano M, Mazoni L, Coppelli A, Del Prato S. COVID-19 in people with diabetes: understanding the reasons for worse outcomes. Lancet Diabetes Endocrinol. 2020;8:782-92.

93. Wu L, Girgis CM, Cheung NW. COVID-19 and diabetes: Insulin requirements parallel illness severity in critically unwell patients. Clin Endocrinol (Oxf). 2020;93:390-3.

94. Ahmed LHM, Butler AE, Dargham SR, Latif A, Ahmed EA, Hassan A, et al. Relationship between total vitamin D metabolites and complications in patients with type 2 diabetes. Biomed Rep. 2021;14:18.

95. Lim S, Shin H, Kim MJ, Ahn HY, Kang SM, Yoon JW, et al. Vitamin D inadequacy is associated with significant coronary artery stenosis in a community-based elderly cohort: the Korean Longitudinal Study on Health and Aging. J Clin Endocrinol Metab. 2012;97:169-78.

96. Shamardl HA, El-Ashmony SM, Kamel HF, Fatani SH. Potential Cardiovascular and Renal Protective Effects of Vitamin D and Coenzyme Q10 in 1-NAME-Induced Hypertensive Rats. Am J Med Sci. 2017;354:190-8.

97. Geleijnse JM. Vitamin D and the prevention of hypertension and cardiovascular diseases: a review of the current evidence. Am J Hypertens. 2011;24:253-62.

98. Yuan W, Pan W, Kong J, Zheng W, Szeto FL, Wong KE, et al. 1,25-dihydroxyvitamin D3 suppresses renin gene transcription by blocking the activity of the cyclic AMP response element in the renin gene promoter. J Biol Chem. 2007;282:29821-30.
99. Aleksova A, Ferro F, Gagno G, Padoan L, Saro R, Santon D, et al. Diabetes Mellitus and Vitamin D Deficiency:Comparable Effect on Survival and a DeadlyAssociation after a Myocardial Infarction. J Clin Med. 2020;9.

100. Manson JE, Cook NR, Lee IM, Christen W, Bassuk SS, Mora S, et al. Vitamin D Supplements and Prevention of Cancer and Cardiovascular Disease. N Engl J Med. 2019;380:33-44.

101. Charoenngam N, Shirvani A, Holick MF. The ongoing D-lemma of vitamin D supplementation for nonskeletal health and bone health. Curr Opin Endocrinol Diabetes Obes. 2019;26:301-5.

102. Yarlagadda K, Ma N, Dore S. Vitamin D and Stroke: Effects on Incidence, Severity, and Outcome and the Potential Benefits of Supplementation. Front Neurol. 2020;11:384.

103. Giannis D, Ziogas IA, Gianni P. Coagulation disorders in coronavirus infected patients: COVID-19, SARS-CoV-1, MERS-CoV and lessons from the past. J Clin Virol. 2020;127:104362.

104. Mohammad S, Mishra A, Ashraf MZ. Emerging Role of Vitamin $\mathrm{D}$ and its Associated Molecules in Pathways Related to Pathogenesis of Thrombosis. Biomolecules. 2019;9.

105. Ginde AA, Mansbach JM, Camargo CA Jr. Association between serum 25-hydroxyvitamin D level and upper respiratory tract infection in the Third National Health and Nutrition Examination Survey. Arch Intern Med. 2009;169:384-90.

106. Sabetta JR, DePetrillo P, Cipriani RJ, Smardin J, Burns LA, Landry ML. Serum 25-hydroxyvitamin d and the incidence of acute viral respiratory tract infections in healthy adults. PLoS One. 2010;5:e11088.

107. Cannell JJ, Vieth R, Umhau JC, Holick MF, Grant WB, Madronich S, et al. Epidemic influenza and vitamin D. Epidemiol Infect. 2006;134:1129-40.

108. Urashima M, Segawa T, Okazaki M, Kurihara M, Wada Y, Ida H. Randomized trial of vitamin D supplementation to prevent seasonal influenza A in schoolchildren. Am J Clin Nutr. 2010;91:1255-60.

109. Martineau AR, Jolliffe DA, Hooper RL, Greenberg L, Aloia JF, Bergman P, et al. Vitamin D supplementation to prevent acute respiratory tract infections: systematic review and meta-analysis of individual participant data. BMJ. 2017;356:i6583.

110. Jolliffe DA, Camargo CA Jr, Sluyter JD, Aglipay M, Aloia JF, Ganmaa D, et al. Vitamin D supplementation to prevent acute respiratory infections: a systematic review and meta-analysis of aggregate data from randomised controlled trials. Lancet Diabetes Endocrinol. 2021;9:276-92.

111. Wu HX, Xiong XF, Zhu M, Wei J, Zhuo KQ, Cheng DY. Effects of vitamin D supplementation on the outcomes of patients with pulmonary tuberculosis: a systematic review and meta-analysis. BMC Pulm Med. 2018;18:108.

112. Martineau AR, Jolliffe DA, Greenberg L, Aloia JF, Bergman P, Dubnov-Raz G, et al. Vitamin D supplementation to prevent acute respiratory infections: individual participant data metaanalysis. Health Technol Assess. 2019;23:1-44.

113. Martineau AR, Cates CJ, Urashima M, Jensen M, Griffiths AP, Nurmatov U, et al. Vitamin D for the management of asthma. Cochrane Database Syst Rev. 2016;9:CD011511.

114. Murdoch DR, Slow S, Chambers ST, Jennings LC, Stewart AW, Priest PC, et al. Effect of vitamin D3 supplementation on upper respiratory tract infections in healthy adults: the VIDARIS randomized controlled trial. JAMA. 2012;308:1333-9.

115. Camargo CA, Sluyter J, Stewart AW, Khaw KT, Lawes CMM, Toop L, et al. Effect of Monthly High-Dose Vitamin D Supplementation on Acute Respiratory Infections in Older Adults: A Randomized Controlled Trial. Clin Infect Dis. 2020;71:311-7.

116. Manaseki-Holland S, Maroof Z, Bruce J, Mughal MZ, Masher MI, Bhutta ZA, et al. Effect on the incidence of pneumonia of vitamin D supplementation by quarterly bolus dose to infants in Kabul: a randomised controlled superiority trial. Lancet. 2012;379:1419-27. 
117. Kahwati LC, LeBlanc E, Weber RP, Giger K, Clark R, Suvada $\mathrm{K}$, et al. Screening for Vitamin D Deficiency in Adults: Updated Evidence Report and Systematic Review for the US Preventive Services Task Force. JAMA. 2021;325:1443-63.

118. Lau FH, Majumder R, Torabi R, Saeg F, Hoffman R, Cirillo JD, et al. Vitamin D Insufficiency is Prevalent in Severe COVID-19. medRxiv. 2020:2020.04.24.20075838.

119. Brenner H. Vitamin D Supplementation to Prevent COVID-19 Infections and Deaths-Accumulating Evidence from Epidemiological and Intervention Studies Calls for Immediate Action. Nutrients. 2021;13.

120. Annweiler C, Hanotte B, de l'Eprevier CG, Sabatier JM, Lafaie L, Celarier T. Vitamin D and survival in COVID-19 patients: A quasi-experimental study. J Steroid Biochem Mol Biol. 2020:105771.

121. Annweiler G, Corvaisier M, Gautier J, Dubee V, Legrand E, Sacco G, et al. Vitamin D Supplementation Associated to Better Survival in Hospitalized Frail Elderly COVID-19 Patients: The GERIA-COVID Quasi-Experimental Study. Nutrients. 2020;12.

122. Sanchez-Zuno GA, Gonzalez-Estevez G, Matuz-Flores MG, Macedo-Ojeda G, Hernandez-Bello J, Mora-Mora JC, et al. Vitamin D Levels in COVID-19 Outpatients from Western Mexico: Clinical Correlation and Effect of Its Supplementation. J Clin Med. 2021;10.

123. Murai IH, Fernandes AL, Sales LP, Pinto AJ, Goessler KF, Duran CSC, et al. Effect of a Single High Dose of Vitamin D3 on Hospital Length of Stay in Patients With Moderate to Severe COVID19: A Randomized Clinical Trial. JAMA. 2021.

124. Bassatne A, Basbous M, Chakhtoura M, El Zein O, Rahme M, El-Hajj Fuleihan G. The link between COVID-19 and VItamin D (VIVID): A systematic review and meta-analysis. Metabolism. 2021;119:154753.

125. Murai IH, Fernandes AL, Sales LP, Pinto AJ, Goessler KF, Duran CSC, et al. Effect of a Single High Dose of Vitamin D3 on Hospital Length of Stay in Patients With Moderate to Severe COVID19: A Randomized Clinical Trial. JAMA. 2021;325:1053-60.

126. Laird E, Rhodes J, Kenny RA. Vitamin D and Inflammation: Potential Implications for Severity of Covid-19. Ir Med J. 2020;113:81.

127. Ilie PC, Stefanescu S, Smith L. The role of vitamin D in the prevention of coronavirus disease 2019 infection and mortality. Aging Clin Exp Res. 2020;32:1195-8.

128. Merzon E, Tworowski D, Gorohovski A, Vinker S, Golan Cohen A, Green I, et al. Low plasma $25(\mathrm{OH})$ vitamin D level is associated with increased risk of COVID-19 infection: an Israeli population-based study. FEBS J. 2020.

129. Hastie CE, Mackay DF, Ho F, Celis-Morales CA, Katikireddi SV, Niedzwiedz CL, et al. Vitamin D concentrations and COVID-19 infection in UK Biobank. Diabetes Metab Syndr. 2020;14:561-5.

130. Hernandez JL, Nan D, Fernandez-Ayala M, Garcia-Unzueta M, Hernandez-Hernandez MA, Lopez-Hoyos M, et al. Vitamin D Status in Hospitalized Patients with SARS-CoV-2 Infection. J Clin Endocrinol Metab. 2020.

131. Reis BZ, Fernandes AL, Sales LP, Santos MD, Dos Santos CC, Pinto AJ, et al. Influence of vitamin D status on hospital length of stay and prognosis in hospitalized patients with moderate to severe COVID-19: a multicenter prospective cohort study. Am J Clin Nutr. 2021.

132. Butler-Laporte G, Nakanishi T, Mooser V, Morrison DR, Abdullah T, Adeleye O, et al. Vitamin D and COVID-19 susceptibility and severity in the COVID-19 Host Genetics Initiative: A Mendelian randomization study. PLoS Med. 2021;18:e1003605.

133. Bolland MJ, Grey A, Avenell A. Effects of vitamin D supplementation on musculoskeletal health: a systematic review, metaanalysis, and trial sequential analysis. Lancet Diabetes Endocrinol. 2018;6:847-58
134. National Heart Lung and Blood Institute Petal Clinical Trials Network, Ginde AA, Brower RG, Caterino JM, Finck L, BannerGoodspeed VM, et al. Early High-Dose Vitamin D3 for Critically Ill, Vitamin D-Deficient Patients. N Engl J Med. 2019;381:2529-40.

135. Forno E, Bacharier LB, Phipatanakul W, Guilbert TW, Cabana MD, Ross K, et al. Effect of Vitamin D3 Supplementation on Severe Asthma Exacerbations in Children With Asthma and Low Vitamin D Levels: The VDKA Randomized Clinical Trial. JAMA. 2020;324:752-60.

136. Kim H, Baek S, Hong SM, Lee J, Jung SM, Lee J, et al. 1,25-dihydroxy Vitamin D3 and Interleukin-6 Blockade Synergistically Regulate Rheumatoid Arthritis by Suppressing Interleukin-17 Production and Osteoclastogenesis. J Korean Med Sci. 2020;35:e40.

137. Arya A, Dwivedi VD. Synergistic effect of vitamin D and remdesivir can fight COVID-19. J Biomol Struct Dyn. 2021;39:4198-9.

138. Recovery Collaborative Group, Horby P, Lim WS, Emberson JR, Mafham M, Bell JL, et al. Dexamethasone in Hospitalized Patients with Covid-19 - Preliminary Report. N Engl J Med. 2020.

139. Dai L, Gao GF. Viral targets for vaccines against COVID-19. Nat Rev Immunol. 2020.

140. Goncalves-Mendes N, Talvas J, Duale C, Guttmann A, Corbin V, Marceau G, et al. Impact of Vitamin D Supplementation on Influenza Vaccine Response and Immune Functions in Deficient Elderly Persons: A Randomized Placebo-Controlled Trial. Front Immunol. 2019;10:65.

141. Wacker M, Holick MF. Sunlight and Vitamin D: A global perspective for health. Dermatoendocrinol. 2013;5:51-108.

142. Zia AA, Komolafe BO, Moten M, Ahokas RA, McGee JE, William Rosenberg E, et al. Supplemental vitamin D and calcium in the management of African Americans with heart failure having hypovitaminosis D. Am J Med Sci. 2011;341:113-8.

143. Wang R, DeGruttola V, Lei Q, Mayer KH, Redline S, Hazra A, et al. The vitamin D for COVID-19 (VIVID) trial: A pragmatic cluster-randomized design. Contemp Clin Trials. 2020:106176.

144. Melhem SJ, Aiedeh KM, Hadidi KA. Effects of a 10-day course of a high dose calciferol versus a single mega dose of ergocalciferol in correcting vitamin D deficiency. Ann Saudi Med. 2015;35:13-8.

145. Kearns MD, Alvarez JA, Tangpricha V. Large, single-dose, oral vitamin D supplementation in adult populations: a systematic review. Endocr Pract. 2014;20:341-51.

146. Han MS, Che X, Cho GH, Park HR, Lim KE, Park NR, et al. Functional cooperation between vitamin $\mathrm{D}$ receptor and Runx2 in vitamin D-induced vascular calcification. PLoS One. 2013;8:e83584.

147. Jung S, Querfeld U, Muller D, Rudolph B, Peters H, Kramer S. Submaximal suppression of parathyroid hormone ameliorates calcitriol-induced aortic calcification and remodeling and myocardial fibrosis in uremic rats. J Hypertens. 2012;30:2182-91.

148. Ayres JS. A metabolic handbook for the COVID-19 pandemic. Nat Metab. 2020;2:572-85.

149. Lim S, Kim MJ, Choi SH, Shin CS, Park KS, Jang HC, et al. Association of vitamin D deficiency with incidence of type 2 diabetes in high-risk Asian subjects. Am J Clin Nutr. 2013;97:524-30.

150. Greiller CL, Martineau AR. Modulation of the immune response to respiratory viruses by vitamin D. Nutrients. 2015;7:4240-70.

151. Hernandez JL, Nan D, Fernandez-Ayala M, Garcia-Unzueta M, Hernandez-Hernandez MA, Lopez-Hoyos M, et al. Vitamin D Status in Hospitalized Patients with SARS-CoV-2 Infection. J Clin Endocrinol Metab. 2021;106:e1343-53.

152. Angelidi AM, Belanger MJ, Lorinsky MK, Karamanis D, ChamorroPareja N, Ognibene J, et al. Vitamin D Status Is Associated With 
In-Hospital Mortality and Mechanical Ventilation: A Cohort of COVID-19 Hospitalized Patients. Mayo Clin Proc. 2021;96:875-86.

153. Abdollahi A, Kamali Sarvestani H, Rafat Z, Ghaderkhani S, Mahmoudi-Aliabadi M, Jafarzadeh B, et al. The association between the level of serum $25(\mathrm{OH})$ vitamin $\mathrm{D}$, obesity, and underlying diseases with the risk of developing COVID-19 infection: A case-control study of hospitalized patients in Tehran. Iran J Med Virol. 2021;93:2359-64.

154. Annweiler C, Hanotte B, Grandin de l'Eprevier C, Sabatier JM, Lafaie L, Celarier T. Vitamin D and survival in COVID-19 patients: A quasi-experimental study. J Steroid Biochem Mol Biol. 2020;204:105771.

155. Lakkireddy M, Gadiga SG, Malathi RD, Karra ML, Raju I, Ragini, et al. Impact of daily high dose oral vitamin D therapy on the inflammatory markers in patients with COVID 19 disease. Sci Rep. 2021;11:10641.

156. Gombart AF. The vitamin D-antimicrobial peptide pathway and its role in protection against infection. Future Microbiol. 2009;4:1151-65.

157. Unger WW, Laban S, Kleijwegt FS, van der Slik AR, Roep BO. Induction of Treg by monocyte-derived DC modulated by vitamin D3 or dexamethasone: differential role for PD-L1. Eur J Immunol. 2009;39:3147-59.

158. Rigby WF, Stacy T, Fanger MW. Inhibition of T lymphocyte mitogenesis by 1,25-dihydroxyvitamin D3 (calcitriol). J Clin Invest. 1984;74:1451-5.

159. Reichel H, Koeffler HP, Tobler A, Norman AW. 1 alpha,25Dihydroxyvitamin D3 inhibits gamma-interferon synthesis by normal human peripheral blood lymphocytes. Proc Natl Acad Sci U S A. 1987;84:3385-9.

160. Tang J, Zhou R, Luger D, Zhu W, Silver PB, Grajewski RS, et al. Calcitriol suppresses antiretinal autoimmunity through inhibitory effects on the Th17 effector response. J Immunol. 2009;182:4624-32.

161. Boonstra A, Barrat FJ, Crain C, Heath VL, Savelkoul HF, O'Garra A. 1alpha,25-Dihydroxyvitamin d3 has a direct effect on naive $\mathrm{CD} 4(+) \mathrm{T}$ cells to enhance the development of Th2 cells. J Immunol. 2001;167:4974-80.

162. Chen S, Sims GP, Chen XX, Gu YY, Chen S, Lipsky PE. Modulatory effects of 1,25-dihydroxyvitamin D3 on human B cell differentiation. J Immunol. 2007;179:1634-47.

163. Lemire JM, Adams JS, Sakai R, Jordan SC. 1 alpha,25dihydroxyvitamin D3 suppresses proliferation and immunoglobulin production by normal human peripheral blood mononuclear cells. J Clin Invest. 1984;74:657-61.

164. Chen Y, Liu W, Sun T, Huang Y, Wang Y, Deb DK, et al. 1,25-Dihydroxyvitamin $\mathrm{D}$ promotes negative feedback regulation of TLR signaling via targeting microRNA-155-SOCS1 in macrophages. J Immunol. 2013;190:3687-95.

165. Cohen-Lahav M, Shany S, Tobvin D, Chaimovitz C, Douvdevani A. Vitamin D decreases NFkappaB activity by increasing IkappaBalpha levels. Nephrol Dial Transplant. 2006;21:889-97.
166. Krishnan AV, Feldman D. Molecular pathways mediating the anti-inflammatory effects of calcitriol: implications for prostate cancer chemoprevention and treatment. Endocr Relat Cancer. 2010;17:R19-38.

167. Haddad Kashani H, Seyed Hosseini E, Nikzad H, Soleimani A, Soleimani M, Tamadon MR, et al. The Effects of Vitamin D Supplementation on Signaling Pathway of Inflammation and Oxidative Stress in Diabetic Hemodialysis: A Randomized, DoubleBlind. Placebo-Controlled Trial Front Pharmacol. 2018;9:50.

168. Jiang F, Yang Y, Xue L, Li B, Zhang Z. 1 $\alpha, 25$-dihydroxyvitamin D3 Attenuates TGF- $\beta$-Induced Pro-Fibrotic Effects in Human Lung Epithelial Cells through Inhibition of Epithelial-Mesenchymal Transition. Nutrients. 2017;9.

169. Sun X, Chen E, Dong R, Chen W, Hu Y. Nuclear factor (NF)kappaB p65 regulates differentiation of human and mouse lung fibroblasts mediated by TGF-beta. Life Sci. 2015;122:8-14.

170. Artaza JN, Norris KC. Vitamin D reduces the expression of collagen and key profibrotic factors by inducing an antifibrotic phenotype in mesenchymal multipotent cells. J Endocrinol. 2009;200:207-21.

171. Gao D, Trayhurn P, Bing C. 1,25-Dihydroxyvitamin D3 inhibits the cytokine-induced secretion of MCP-1 and reduces monocyte recruitment by human preadipocytes. Int J Obes (Lond). 2013;37:357-65.

172. Dancer RC, Parekh D, Lax S, D'Souza V, Zheng S, Bassford $\mathrm{CR}$, et al. Vitamin D deficiency contributes directly to the acute respiratory distress syndrome (ARDS). Thorax. 2015;70:617-24.

173. Gysemans CA, Cardozo AK, Callewaert H, Giulietti A, Hulshagen L, Bouillon R, et al. 1,25-Dihydroxyvitamin D3 modulates expression of chemokines and cytokines in pancreatic islets: implications for prevention of diabetes in nonobese diabetic mice. Endocrinology. 2005;146:1956-64.

174. Del Pino-Montes J, Benito GE, Fernandez-Salazar MP, Covenas R, Calvo JJ, Bouillon R, et al. Calcitriol improves streptozotocininduced diabetes and recovers bone mineral density in diabetic rats. Calcif Tissue Int. 2004;75:526-32.

175. Wei Z, Yoshihara E, He N, Hah N, Fan W, Pinto AFM, et al. Vitamin D Switches BAF Complexes to Protect beta Cells. Cell. 2018;173:1135-49 e15.

176. Cheng Q, Li YC, Boucher BJ, Leung PS. A novel role for vitamin $D$ : modulation of expression and function of the local reninangiotensin system in mouse pancreatic islets. Diabetologia. 2011;54:2077-81.

177. Bouillon R. Vitamin D and cardiovascular disorders. Osteoporos Int. 2019;30:2167-81.

178. Lu Q, Wan Z, Guo J, Liu L, Pan A, Liu G. Association between serum 25-hydroxyvitamin D concentrations and mortality among adults with prediabetes. J Clin Endocrinol Metab. 2021.

Publisher's Note Springer Nature remains neutral with regard to jurisdictional claims in published maps and institutional affiliations. 